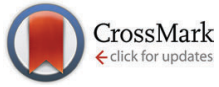

Cite this: J. Mater. Chem. B, 2015, 3, 4626

Received 10th April 2015, Accepted 11th May 2015

DOI: $10.1039 / c 5 t b 00654 f$

www.rsc.org/MaterialsB

\section{Strontium modified calcium phosphate cements - approaches towards targeted stimulation of bone turnover}

\begin{abstract}
Matthias Schumacher* and Michael Gelinsky
Making use of the potential of calcium phosphates to host a variety of ions in their crystal lattice, ion substitution of calcium phosphate bone cements has become the subject of intense investigations in the last few years, since this approach allows one to stabilize a bone defect and to locally deliver therapeutic ions into a specific defect site at the same time. In this respect significant attention has been given to strontium ions $\left(\mathrm{Sr}^{2+}\right)$ lately. Strontium possesses the unique potential to both stimulate new bone formation and inhibit cell-driven bone resorption and thus has been used successfully in systemic osteoporosis therapy. Strontium doping of calcium phosphate bone cements might allow making use of this dual effect to promote local bone defect healing. The goal of this review is to provide an overview of different routes that have been employed to obtain strontium-containing calcium phosphate bone cements and describe their material characteristics as well as their biological properties based on cell culture and animal studies.
\end{abstract}

\section{Introduction}

Biomaterials, in terms of materials intended to come into contact with living tissue or to be implanted into a living

Centre for Translational Bone, Joint and Soft Tissue Research, Medical Faculty and University Hospital, Technische Universität Dresden, Dresden, Germany.

E-mail: matthias.schumacher@tu-dresden.de

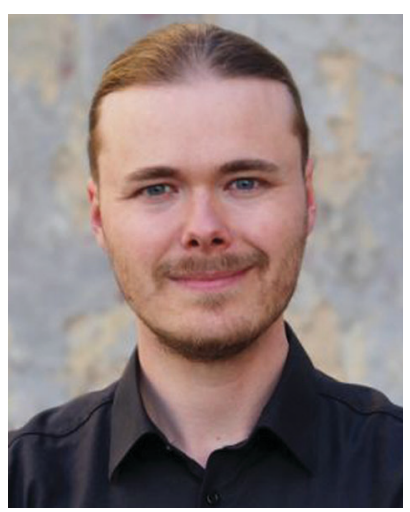

Matthias Schumacher

Science. His research interests include the development of biomaterials, with focus on hard tissue reconstruction, calcium phosphates and tissue engineering as well as rapid prototyping of biomaterials. organism, are usually described on the basis of their specific degree of biocompatibility. Although various definitions of "biocompatibility" exist, most of them are based on absence of negative tissue reaction and/or formation of a fibrous interface. ${ }^{1}$ For example, materials in contact with bone tissue are required to allow the formation of a strong bone-material interface in order to support the mechanical integrity of the host bone. Biomaterials for hard tissue repair have been in the

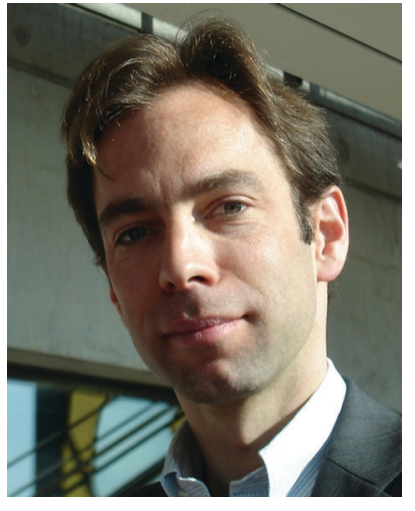

Michael Gelinsky
Michael Gelinsky is a Professor at the Medical Faculty of Dresden University of Technology (TU Dresden, Germany) and head of the Centre for Translational Bone, Joint and Soft Tissue Research. He obtained his PhD in Chemistry from Freiburg University (Germany), has headed a research group at the Max Bergmann Centre of Biomaterials (TU Dresden, Institute for Materials Science) and is a founder member of the Centre for Regenerative Therapies Dresden (CRTD). His multidisciplinary group is focused on novel therapeutic options for musculoskeletal diseases including biomaterial development, stem cell research and tissue engineering. His lab also has started to explore new technologies of additive manufacturing and biofabrication for medical applications. 
focus of research for many years now. Calcium phosphates (CaP), in particular hydroxyapatite (HA) and brushite (DCPA), are widely used in bone graft applications as well as in coatings of metallic implants, since their chemical resemblance to the mineral part of the natural bone offers excellent biocompatibility. ${ }^{1,2}$ Since some mixtures of calcium phosphates can, once in contact with water, undergo a hydraulic setting reaction into either HA or DCPA, a number of self-setting cements have been developed of which many are in clinical use today. Calcium phosphate bone cements (CPC) in general can be shaped into a specific bone defect during implantation, are highly biocompatible and are bioresorbable. ${ }^{3}$ However, only recently concepts beyond "simple" biocompatibility have been developed: on the one hand tissue engineering aims at the implantation of cell seeded, functional biomaterial scaffolds; on the other hand materials with an intrinsic potential to influence the host tissue have been proposed. Such "third generation biomaterials" are meant to (locally) evoke a specific cellular response based on the cellmaterial interaction. ${ }^{4}$ These may be materials that contain and locally release drugs upon implantation as well as materials which are composed of biologically effective components that are released as soon as the implants degrade in the body. Much effort has been made to investigate the potential of $\mathrm{CaP}$ and CPC comprising biologically potent ions, such as silicate, ${ }^{5-8}$ magnesium $^{9-11}$ and many others. ${ }^{2,12}$ Whilst drug delivery from CaP bone cements has been reviewed in detail recently, ${ }^{13}$ this study is focussed on cements comprising biologically highly effective strontium ions $\left(\mathrm{Sr}^{2+}\right)$. Strontium has been proposed to possess both a bone formation stimulating and at the same time anti-resorptive effect and is thus used in systemic osteoporosis therapy. ${ }^{14}$

Our aim is to provide a rationale for the development of Sr-laden CaP bone cements for the treatment of bone defects, an overview of different routes that have been employed to obtain such cements as well as their material characteristics and in vitro and in vivo properties.

\subsection{Strontium in bone}

Strontium (Sr) is an alkaline earth metal accounting for approx. $0.02-0.03 \%$ of the earth's crust. ${ }^{15,16}$ Its concentration in drinking water varies with geographic region, but is generally low, for example less than $1 \mathrm{mg} \mathrm{ml}^{-1}$ in the United States. ${ }^{16}$ A typical diet contains about $2-4 \mathrm{mg}$ Sr per day, ${ }^{15,16}$ and the secretion of Sr exceeds that of $\mathrm{Ca}$, accounting for a fairly low bioavailability of orally ingested $\mathrm{Sr}$ of $\sim 20 \% .{ }^{17}$ Since $\mathrm{Sr}^{2+}$ is generally regarded as bone-seeking and thus could remain in the body for a long time once ingested, the interest in strontium metabolism arose from radioactive ${ }^{90} \mathrm{Sr}$ atmospheric contamination following the nuclear weapon tests since $1945 .^{15}$ Radioactive isotopes of $\mathrm{Sr}$ have also been used for diagnostic purposes. ${ }^{15}$ Strontium was discovered to follow the metabolic pathways and signalling principles known for calcium, although the response to $\mathrm{Sr}^{2+}$ tends to be weaker. Strontium shows a comparable protein binding capacity to that of $\mathrm{Ca}$ and is mostly deposited in the bone mineral. ${ }^{15}$ In 1952 Shorr and Carter described an increased calcium absorption and thus bone formation under the influence of strontium lactate $\left(\mathrm{SrC}_{6} \mathrm{H}_{12} \mathrm{O}_{6} \cdot x \mathrm{H}_{2} \mathrm{O}\right) .{ }^{18} \mathrm{~A}$ first clinical trial

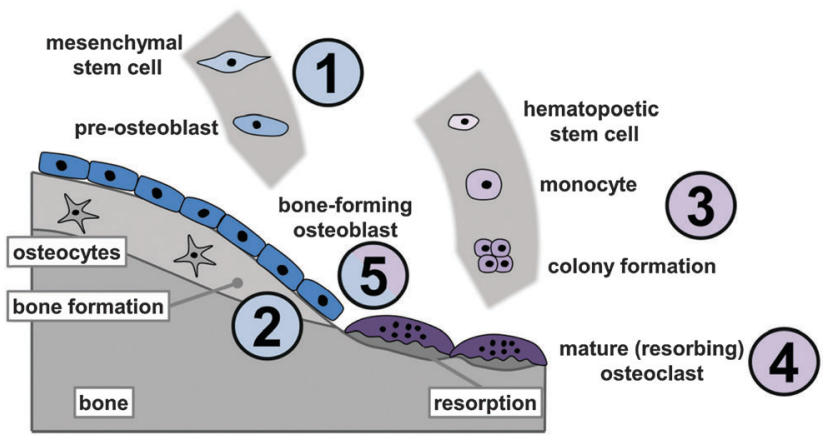

Fig. 1 Effects of $\mathrm{Sr}^{2+}$ ions on bone metabolism: stimulation of osteoblastprecursor proliferation and osteogenic differentiation (1), increase of bone mineralisation by osteoblasts (2), reduced osteoclast-precursor recruitment and osteoclastogenesis (3), decreased resorption activity and increased apoptosis of mature osteoclasts (4) as well as interaction with the osteoblast/osteoclast paracrine signalling (5).

where patients with postmenopausal osteoporosis received up to $1.75 \mathrm{~g} \mathrm{~d}^{-1} \mathrm{Sr}$ in the form of strontium lactate over a period between 3 months and 3 years showed an increase in bone mass under $\mathrm{Sr}$ administration and a potential benefit in osteoporosis therapy without any side effects. ${ }^{19,20}$ Systematic studies revealed the bone conserving effect of divalent strontium in ovariectomized (OVX) rats, ${ }^{21}$ until two clinical phase III trials showed a significant increase in bone mass under the influence of $2 \mathrm{~g} \mathrm{~d}^{-1} S$-12911 (strontium ranelate, SrRan) in postmenopausal women. ${ }^{22,23}$

Unlike most other drugs used in osteoporosis therapy, $\mathrm{Sr}$ exerts a dual effect on bone remodelling, being able to enhance osteoblast activity and thus increase new bone formation and at the same time inhibit osteoclast activity and thus reduce cellular bone resorption (Fig. 1). ${ }^{24-27}$ Several in vitro studies confirmed this twofold effect of $\mathrm{Sr}$ on bone metabolism. For example, osteoblast precursor proliferation and expression of extracellular matrix proteins are increased by $\sim 10^{-3} \mathrm{mM} \mathrm{Sr}^{2+}$, and osteoblast-mediated bone formation is stimulated in the presence of $2-5 \mu \mathrm{g} \mathrm{ml}^{-1}\left(2.3-5.7 \times 10^{-3} \mathrm{mM}\right) \mathrm{Sr}^{2+} \cdot{ }^{28,29}$ Although the exact mechanism of how $\mathrm{Sr}$ affects bone cells remains unknown, it has been proposed that $\mathrm{Sr}$ acts on the calcium sensing receptor (CaSR) expressed by bone cells as a calcium-like entity and thus interacts with signalling pathways associated with the Ca-driven regulation of bone metabolism. ${ }^{30,31}$ Furthermore, an increase of $\beta$-catenin expression indicating an enhanced transcription of osteogenic factors, a decrease in Wnt-pathway inhibitors as well as an enhanced prostaglandin-expression under the influence of $\mathrm{Sr}$ have been described. ${ }^{30,32}$ Interestingly, similar concentrations of Sr inhibit the formation of osteoclasts and their resorption activity through either paracrine signalling ${ }^{33-35}$ or even the induction of osteoclast apoptosis. ${ }^{36}$

\subsection{Calcium phosphate bone cements}

First described by LeGeros as well as Brown and Chow in the 1980s, calcium phosphate cements (CPC) have become a frequently used biomaterial in clinical application today. ${ }^{37-39}$ CPC are hydraulic cements and are usually prepared by mixing 
Table 1 Calcium phosphate species frequently used to prepare $\mathrm{CPC}^{3,40}$

\begin{tabular}{|c|c|c|c|c|}
\hline Name & Abbreviation & Chemical formula & $\mathrm{Ca} / \mathrm{P}$ ratio & $\mathrm{pH}^{a}$ \\
\hline Calcium dihydrogen phosphate (anhydrous) & MCPA & $\mathrm{Ca}\left(\mathrm{H}_{2} \mathrm{PO}_{4}\right)_{2}$ & 0.5 & - \\
\hline Octacalcium phosphate & OCP & $\mathrm{Ca}_{8}\left(\mathrm{HPO}_{4}\right)_{2}\left(\mathrm{PO}_{4}\right)_{4} \cdot 5 \mathrm{H}_{2} \mathrm{O}$ & 1.33 & $5.5-7.0$ \\
\hline$\alpha$-Tricalcium phosphate & $\alpha-$ TCP & $\alpha-\mathrm{Ca}_{3}\left(\mathrm{PO}_{4}\right)_{2}$ & 1.5 & - \\
\hline$\beta$-Tricalcium phosphate & $\beta$-ТCP & $\beta-\mathrm{Ca}_{3}\left(\mathrm{PO}_{4}\right)_{2}$ & 1.5 & - \\
\hline Hydroxyapatite & HA & $\mathrm{Ca}_{5}\left(\mathrm{PO}_{4}\right)_{3} \mathrm{OH}$ & 1.67 & $>9.5$ \\
\hline Tetracalcium phosphate & TTCP & $\mathrm{Ca}_{4}\left(\mathrm{PO}_{4}\right)_{2} \mathrm{O}$ & 2.0 & - \\
\hline
\end{tabular}

one or more calcium orthophosphate powders (the so-called precursor) with an aqueous liquid. A list of $\mathrm{CaP}$ phases frequently used to prepare CPC is given in Table 1 .

Upon mixing of the precursor with the liquid phase a paste forms that will self-set and harden via a hydraulic reaction, characterised by dissolution of the precursor components and the precipitation of a thermodynamically more stable setting product. Mechanical integrity results from the entanglement of the newly formed crystals. ${ }^{41}$ Although a large number of CPC formulations have been proposed, all of them set into one of two possible end products at $37^{\circ} \mathrm{C}$ : hydroxyapatite $\left(\mathrm{Ca}_{5}\left(\mathrm{PO}_{4}\right)_{3}(\mathrm{OH}), \mathrm{HA}\right)$, as the most stable phase at $\mathrm{pH}$ values $>4.2$, or brushite $\left(\mathrm{CaHPO}_{4} \cdot 2 \mathrm{H}_{2} \mathrm{O}, \mathrm{DCPD}\right)$, which is the result of the setting reaction at $\mathrm{pH}<4.2 .^{3}$ The chemical nature of the reaction can, in principle, be either an acid-base reaction (e.g. the brushite-forming reaction of the acidic MCPM with slightly basic $\beta$-TCP) or the conversion of a metastable phase, such as amorphous calcium phosphate (ACP) or $\alpha$-TCP, into a more stable one. ${ }^{3,40}$ The setting reaction will lead to the hardening of the paste within a characteristic time span (setting time).

Apatite-forming cements. Since the mineral part of natural bone is composed of Ca-deficient hydroxyapatite containing a variety of substitutions such as carbonate, magnesium, sodium, etc. (referred to as "bone apatite"), ${ }^{1}$ the choice of HA-forming cements for bone repair is self-evident. The classical apatite-forming cement of Brown and Chow is based on the reaction of basic tetracalcium phosphate with calcium hydrogen phosphate (eqn (1)): $:^{38}$

$$
\mathrm{Ca}_{4}\left(\mathrm{PO}_{4}\right)_{2} \mathrm{O}+\mathrm{CaHPO}_{4} \rightarrow \mathrm{Ca}_{5}\left(\mathrm{PO}_{4}\right)_{3} \mathrm{OH}
$$

Numerous other cement formulations have been proposed based on the setting reaction of one more acidic and one more basic $\mathrm{CaP}$ component, e.g. combinations of $\alpha$-TCP with MCPM and $\mathrm{CaO}$ or the reaction of TTCP, $\beta$-TCP and MCPM. ${ }^{42,43}$ Driessens and co-workers developed a cement setting into carbonated, Ca-deficient HA more similar to the natural bone apatite (eqn (2)). ${ }^{44}$

$$
\begin{aligned}
& \alpha-\mathrm{Ca}_{3}\left(\mathrm{PO}_{4}\right)_{2}+\mathrm{CaHPO}_{4}+\mathrm{CaCO}_{3}+8 \mathrm{H}_{2} \mathrm{O} \\
& \quad \rightarrow \mathrm{Ca}_{10-x-y}\left[\left(\mathrm{HPO}_{4}\right)_{x}\left(\mathrm{CO}_{3}\right)_{y}\right]\left(\mathrm{HPO}_{4}\right)_{5} \mathrm{OH}+(6+y) \mathrm{H}^{+}
\end{aligned}
$$

One second category is cements derived from a one-component precursor that set via the conversion of a less stable CaP phase into hydroxyapatite upon mixing with water, e.g. the hydrolysis of $\alpha$-TCP and its re-precipitation into CDHA or the conversion of ACP into HA. ${ }^{45,46}$ Apatite-forming cements possess a very low solubility according to their setting product: CDHA has a slightly higher solubility than stoichiometric HA (Table 2). This leads to relatively low physico-chemical degradation. ${ }^{47}$ However, apatite cements can be resorbed in vivo via cellular activity (osteoclastic resorption), ${ }^{48}$ although the degree of resorption seems to depend on the actual setting product (HA or CDHA), the respective degree of crystallinity and the porosity. Mechanical characterisation revealed that compressive strength values of completely set HA-forming cements are up to $70-80 \mathrm{MPa}^{40,41}$

Brushite-forming cements. Invented by Mirtchi and Lemaître in 1987, brushite is the second possible end product of hydraulic CPC reactions. ${ }^{57}$ The most common formulation is based on an equimolar mixture of $\beta$-TCP and MCPM as given in eqn (3): ${ }^{58}$

$$
\beta-\mathrm{Ca}_{3}\left(\mathrm{PO}_{4}\right)_{2}+\mathrm{Ca}\left(\mathrm{H}_{2} \mathrm{PO}_{4}\right)_{2} \cdot \mathrm{H}_{2} \mathrm{O}+7 \mathrm{H}_{2} \mathrm{O} \rightarrow 4 \mathrm{CaHPO}_{4} \cdot 2 \mathrm{H}_{2} \mathrm{O}
$$

Table 2 Solubility of various CPC and SrCPC components and setting products

Components with low solubility

\begin{tabular}{llcl}
\hline Formula & $\begin{array}{l}\text { Solubility at } 25{ }^{\circ} \mathrm{C} \\
{\left[-\log \left(K_{\text {sp }}\right)\right]}\end{array}$ & $\begin{array}{l}\text { Solubility at } 25{ }^{\circ} \mathrm{C} \\
{\left[\mathrm{mg}^{-1}\right]}\end{array}$ & Ref. \\
\hline$\alpha$-TCP & 25.5 & 2.5 & 49 and 50 \\
$\beta-\mathrm{TCP}$ & 28.9 & 0.5 & 49 and 50 \\
$\mathrm{CaHPO}_{4}$ (DCPA) & 6.90 & 48 & 49 and 50 \\
$\mathrm{SrHPO}_{4}$ (DSPA) & $6.7-6.9$ & 63 & 51 \\
$\mathrm{CaCO}_{3}$ & 4.90 & 14 & 52 and 53 \\
$\mathrm{SrCO}_{3}$ & 8.10 & 10 & 52 and 53 \\
$\mathrm{CDHA}$ & $\sim 85.1$ & $\sim 9.4$ & 3 and 49 \\
$\mathrm{HA}$ & $58.4-116.8$ & 0.3 & 3,49 and 50 \\
DCPD/brushite & 6.59 & 88 & 49 and 50 \\
SrHA & $115-117$ & - & 54 and 55 \\
$(0.3-10 \%$ Sr & \\
Sr-brushite & Increased & - & 56 \\
& $($ comp. to brushite) & & 49 and 50 \\
TTCP & $38-44$ & 0.7 &
\end{tabular}

Highly soluble components

\begin{tabular}{lcl}
\hline Formula & Solubility at $25{ }^{\circ} \mathrm{C}\left[\mathrm{g} \mathrm{l}^{-1}\right]$ & Ref. \\
\hline $\mathrm{SrCl}_{2}$ & 1060 & 52 and 53 \\
$\mathrm{Sr}\left(\mathrm{NO}_{3}\right)_{2}$ & 800 & 52
\end{tabular}


Other formulations comprise $\beta$-TCP and phosphoric acid or MCPM, tetracalcium phosphate and $\mathrm{CaO}$, but are all based on an acid-base reaction mechanism. ${ }^{59,60}$ In general, brushite cements possess a much higher solubility (Table 2) and thus a higher degradation rate than HA under physiological conditions. ${ }^{61}$ Moreover, because of its metastable nature, at $\mathrm{pH}>6$ brushite hydrolyses into CDHA over time, which may lead to the release of orthophosphoric acid that could cause the inflammatory tissue response sometimes reported after implantation of large quantities of brushite-forming cements. ${ }^{62}$ Brushite can also be resorbed by cellular activity in vitro and in vivo. ${ }^{61,63}$ However, setting of brushite cements takes place at low $\mathrm{pH}$ values and such acidification may not only complicate the cellular reaction in vitro but also hamper tissue integration in vivo. Brushite cements are mechanically slightly weaker than apatite forming cements. Compressive strength values of up to $60 \mathrm{MPa}$ have been reported. ${ }^{40}$

\section{Strontium-modified CaP cements}

The potential of CPC to host various ions like $\mathrm{Na}^{+}, \mathrm{K}^{+}, \mathrm{Mg}^{2+}$, $\mathrm{Sr}^{2+}, \mathrm{CO}_{3}{ }^{2-}, \mathrm{Cl}^{-}$, etc. has been described before. ${ }^{41}$ Given the ability of some ions (calcium, phosphate, strontium, silicate, zinc and magnesium) to trigger bone cell response and their advantages over bioactive proteins like growth factors, such as lower cost and better stability, the local release of therapeutically potent ions from an implanted bone cement could have big impact on bone healing strategies. ${ }^{13}$ In 2000 , Li et al. published the development of a SrHA (strontium-substituted HA) containing resin-based bone cements with good mechanical and in vitro characteristics. ${ }^{64}$ Recently, the synthesis and characterisation of Sr-containing CPC (SrCPC) has become the focus of many studies. From a crystallographic point of view, the basis of all those developments is that strontium, as some other divalent cations, can be integrated into the crystal lattice of calcium phosphates on $\mathrm{Ca}^{2+}$ positions over a wide range of concentrations preserving the respective crystal structure. ${ }^{56,65,66}$ It was reported that $\mathrm{Sr}^{2+}$ can substitute $\mathrm{Ca}^{2+}$ in a number of CaP phases, including amorphous calcium phosphate, hydroxyapatite, octacalcium phosphate and brushite ${ }^{67}$ In hydroxyapatite, $\mathrm{Sr}^{2+}$ can occupy either the $\mathrm{Ca}(\mathrm{I})$ or $\mathrm{Ca}(\mathrm{II})$ position, although $\mathrm{Ca}(\mathrm{I})$ is only preferred at very low levels of substitution. ${ }^{68}$ Due to its larger ionic radius $\left(\mathrm{Ca}^{2+}: 148 \mathrm{pm} ; \mathrm{Sr}^{2+}\right.$ : $158 \mathrm{pm}$ in hexagonal hydroxyapatite) ${ }^{69}$ strontium substitution causes a linear increase of apatite lattice parameters. ${ }^{54,68,70}$ At higher concentrations Sr substitution has been shown to decrease the crystallinity. ${ }^{68,71}$ In the case of brushite, substitution of $\mathrm{Ca}^{2+}$ by $\mathrm{Sr}^{2+}$ ions is not limited to specific Ca sites and causes an expansion of the unit cell volume and thus a shift in the X-ray diffraction peaks towards lower diffraction angles. ${ }^{67}$ The same effect can be found in $\alpha$ - and $\beta$-TCP. ${ }^{72-74} \beta$-TCP was shown to possess the ability to host up to 80 at\% strontium which is accompanied by a linear increase of the lattice parameters. ${ }^{72}$ Lattice distortion induced by the larger $\mathrm{Sr}^{2+}$ ions has been found to be in charge of the increased solubility of substituted apatite and brushite. ${ }^{5,56}$ However, even fully substituted apatite

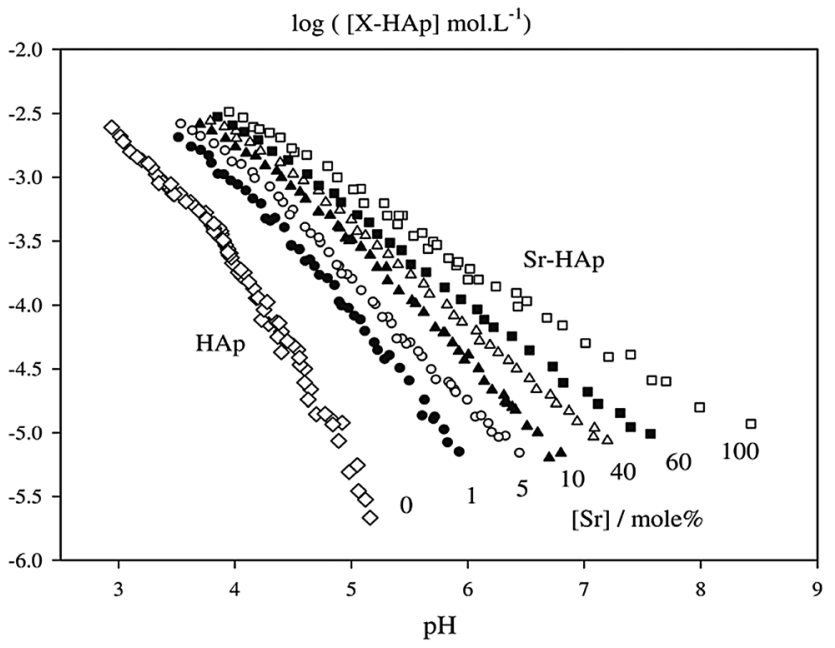

Fig. 2 Solubility isotherms of hydroxyapatite ("HAp") and "Sr-HAp" with different degrees of Sr-substitution. Reprinted from H. B. Pan, et al., Solubility of strontium-substituted apatite by solid titration, Acta Biomater., 2009, 5(5), 1678-1685, with permission from Elsevier.

(Ca free strontium-apatite) possesses a solubility higher than that of pure HA (Fig. 2) despite being as highly ordered as HA. ${ }^{55}$ Thus substitution could help to enhance in vivo degradability and, consequently, osseointegration of SrCPC. Moreover, Sr can affect the conversion of $\alpha$-TCP to CDHA and could therefore be used as a tool to modulate the setting characteristics. ${ }^{75}$ In particular, $\mathrm{Sr}^{2+}$ (and other divalent cations such as $\mathrm{Mg}^{2+}, \mathrm{Ba}^{2+}$, $\mathrm{Zn}^{2+}$ and $\left.\mathrm{Cu}^{2+}\right)^{76-78}$ has been shown to block $\alpha$-TCP hydrolysis. In the context of CPC this could decelerate conversion into CDHA and thus setting, a principle that was recently employed to prevent aqueous $\alpha$-TCP pastes from setting and thus to obtain storable cement precursor pastes that can be activated upon mixing with a second, $\mathrm{Ca}^{2+}$ containing liquid. ${ }^{78}$ The presence of $\mathrm{Sr}^{2+}$ has further been shown to affect the rate of apatite nucleation; ${ }^{79}$ in particular, under the influence of $\mathrm{Sr}^{2+}$ apatite deposition on HA samples from a $\mathrm{Ca}^{2+}$ and $\mathrm{Sr}^{2+}$ containing solution has been demonstrated, but, interestingly, this effect was less pronounced if the substrate was SrHA. ${ }^{54}$

In principle there are four possible ways to obtain strontium containing or strontium substituted calcium phosphate cements: one can (a) add Sr-containing phases to an existing cement system, (b) substitute calcium phases in the cement precursor powder by their strontium analogues (e.g. substitution of $\mathrm{CaHPO}_{4}$ by $\mathrm{SrHPO}_{4}$ ), (c) use Sr-substituted reactive CaP phases as a component in the precursor (e.g. Sr-substituted $\alpha$-TCP) or (d) use a strontium-salt-containing solution as liquid phase during cement paste preparation (Fig. 3).

As for CPC, setting of SrCPC depends on the solubility of the precursor powder components. ${ }^{80}$ During setting, the $\mathrm{Sr}$ component can either act as an inert filler or undergo dissolution and re-precipitation as the other precursor components or crystallise from the liquid. Besides the respective solubility of the precursor phases the overall $(\mathrm{Ca}+\mathrm{Sr}) / \mathrm{P}$ ratio of the powder has to be taken into account, since both an excess or shortage of cations $\left(\mathrm{Ca}^{2+}, \mathrm{Sr}^{2+}\right)$ can inhibit the setting reaction, alter the 


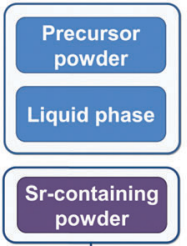

a)

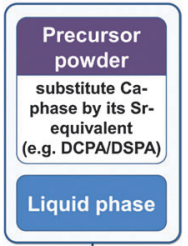

b)

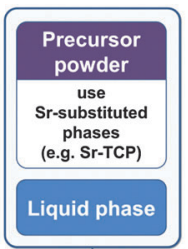

c)

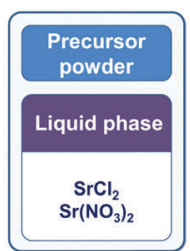

d)
Sr-containing CPC

Fig. 3 Processing routes towards SrCPC: addition of Sr-containing reagents (a), substitution of reagents by their Sr-equivalents (b), use of Sr-substituted reagents in the precursor (c) and use of a Sr-containing liquid (d).

setting product or decrease the reaction yield. Regarding the end-product of the setting reaction, cement matrices with embedded Sr-rich clusters (those systems where the Sr component does not undergo complete dissolution) can be distinguished from monophasic apatite matrices with $\mathrm{Sr}^{2+}$ substituted into the crystal lattice. Another mechanism has been proposed by Kuang et al., who attribute the initial hardening of the cement to a fast chelate reaction of $\mathrm{Ca} / \mathrm{Sr}$ ions and carboxy groups from carboxylic acids (such as citric acid) in the cement liquid. ${ }^{81,82}$

Table 3 summarises different approaches towards preparation of SrCPC and indicates the mono- or biphasic nature of the set cement.

\subsection{Apatite-forming formulations}

Certainly the most straightforward way to introduce Sr into a cement is the addition of a Sr-containing phase to the cement powder. Wang et al. intermixed $\mathrm{SrCO}_{3}$ with an ACP/DCPD cement precursor by intense milling and found a retarded setting of the cement into HA. The set cement was characterised by a smaller grain size, which can be attributed to the milling process. However, $\mathrm{SrCO}_{3}$ was still detected in the XRD spectra of the set cements and thus Sr did not quantitatively substitute into the apatite lattice. ${ }^{87}$ Another cement was obtained by addition of $\mathrm{SrCO}_{3}$ particles with a size of $\sim 10 \mu \mathrm{m}$ to a cement containing $\alpha$-TCP, DCPA, HA and $\mathrm{CaCO}_{3}$. Here, no additional milling step was used, and therefore the set cement was characterised by relatively large $\mathrm{SrCO}_{3}$ clusters embedded in an apatite matrix. ${ }^{86}$ Furthermore, with the aim of mechanical reinforcement of the cement, SrHA whiskers prepared using a hydrothermal synthesis route were added to a $\beta$-TCP/DCPD cement precursor by Shen and co-workers. ${ }^{92}$

Another approach to obtain Sr-containing HA cements is the substitution of Ca-phases by their Sr analogues. For example, using the cementing reaction of DCPA/TTCP into hydroxyapatite upon mixing with phosphoric acid, DCPA can be substituted by its strontium analogue strontium hydrogen phosphate $\left(\mathrm{SrHPO}_{4}, \mathrm{DSPA}\right)$. In this way, Sr-substituted apatite cements with a $\mathrm{Sr} /(\mathrm{Sr}+\mathrm{Ca})$ ratio of up to 0.1 were prepared by Guo et al ${ }^{83,84}$

Since mixtures of DCPD and $\mathrm{CaCO}_{3}$ can set into HA, one strategy to obtain SrHA cements is to replace $\mathrm{CaCO}_{3}$ in the precursor by $\mathrm{SrCO}_{3}$. Following this approach, precursors composed of DCPD and various $\mathrm{CaCO}_{3}-\mathrm{SrCO}_{3}$ mixtures were prepared by Tadier $e t$ al. to obtain cements with up to $8 \mathrm{wt} \%$ $\mathrm{Sr}^{85}$ In contrast to the above-mentioned systems, the setting product was biphasic: the set cement was composed of a mixture of hydroxyapatite and $\mathrm{SrCO}_{3}$ and no SrHA could be detected. Similarly, no homogeneous Sr-distribution was achieved by a precursor mixture of DCPD and amorphous calcium phosphate (ACP) in which the latter was partially replaced by amorphous strontium phosphate (ASP). Although total $\mathrm{Sr} /(\mathrm{Sr}+\mathrm{Ca})$ ratios between 0.025 and 0.1 could be obtained the set cement was composed of coexistent HA and SrHA. ${ }^{89}$ On the other hand, in an $\alpha$-TCP/DCPA/HA/ $\mathrm{CaCO}_{3}$ cement system setting into CDHA, substitution of $\mathrm{CaCO}_{3}$ by $\mathrm{SrCO}_{3}$ in the precursor powder mixture was shown to result in the formation of a monophasic, Sr-substituted apatite matrix and enhanced mechanical properties after setting. ${ }^{86}$ Baier et al. replaced both DCPA and $\mathrm{CaCO}_{3}$ by DSPA and $\mathrm{SrCO}_{3}$ in an $\alpha$-TCP cement and obtained good in vivo results; however, no material

Table 3 Selected Sr-containing cement formulations and setting products ( $m$ : monophasic cement matrix, b: biphasic cement matrix)

\begin{tabular}{|c|c|c|c|c|c|}
\hline Sr-source & Solid or liquid & Precursor phases & Setting products & Mono or biphasic & Ref. \\
\hline $\mathrm{SrCO}_{3}$ & $\mathrm{~s}$ & $\mathrm{CaCO}_{3}, \mathrm{SrCO}_{3}, \mathrm{DCPD}$ & $\mathrm{HA}, \mathrm{SrCO}_{3}$ & $\mathrm{~b}$ & 85 \\
\hline $\mathrm{SrCO}_{3}$ & $\mathrm{~s}$ & $\alpha$-TCP, HA, DCPA, $\mathrm{CaCO}_{3} / \mathrm{SrCO}_{3}$ & $\mathrm{HA}, \mathrm{SrCO}_{3}$ & $\mathrm{~b}$ & 86 \\
\hline $\mathrm{SrCO}_{3}$ & $\mathrm{~s}$ & $\mathrm{DCPD}, \mathrm{CaO} / \mathrm{SrCO}_{3}$ & SrHA & $\mathrm{b}$ & 88 \\
\hline ASP & $\mathrm{s}$ & ACP, ASP, DCPD & SrHA, HA & $\mathrm{b}$ & 89 \\
\hline SrACP & $\mathrm{s}$ & SrACP, DCPA & $\mathrm{SrHA}, \mathrm{SrCO}_{3}$ after ageing SrHA & $\mathrm{b}$ & 90 \\
\hline DSPA & $\mathrm{s}$ & TTCP, DCPA/DSPA ${ }^{a}$ & SrHA & $\mathrm{m}$ & 81 \\
\hline SrHA $\mathrm{W}^{b}$ & $\mathrm{~s}$ & $\beta$-TCP, DCPA, Sr-HA-whiskers & Not characterized & $\mathrm{b}$ & 92 \\
\hline $\mathrm{SrCl}_{2}$ & 1 & $\alpha$-TCP/gelatin, DCPD & SrCDHA & $\mathrm{m}$ & 75 \\
\hline $\mathrm{SrCl}_{2}$ & 1 & $\mathrm{CaCO}_{3}, \mathrm{DCPD}$ & SrHA & $\mathrm{m}$ & 85 \\
\hline $\mathrm{SrCl}_{2}$ & 1 & $\alpha$-ТCP & SrHA & $\mathrm{m}$ & 93 \\
\hline $\mathrm{Sr}\left(\mathrm{NO}_{3}\right)_{2}$ & 1 & $\alpha$-ТCP, ТTCP & SrHA & $\mathrm{m}$ & 94 \\
\hline
\end{tabular}

ACP: amorphous calcium phosphate, ASP: amorphous strontium phosphate, DCPA: monetite, DCPD: brushite, DSPA: strontium hydrogen phosphate anhydrous, SrACP: strontium-substituted ACP, Sr- $\alpha$-TCP: strontium-substituted $\alpha$-TCP, SrCDHA: Sr containing Ca-deficient HA, TTCP: tetra-calcium phosphate. ${ }^{a}$ Liquid component did contain polymeric additives. ${ }^{b}$ Whiskers. 
characterisation of that cement was published. ${ }^{91} \mathrm{SrCO}_{3}$ was also successfully used to gradually replace $\mathrm{CaO}$ in a DCPD/CaO cement, resulting in the formation of a SrHA matrix via several intermediate steps. ${ }^{88}$ However, the $\mathrm{Sr} /(\mathrm{Ca}+\mathrm{Sr})$ ratio that can be achieved by substituting a $\mathrm{Ca}$ phase by its $\mathrm{Sr}$ analogue is limited to the fraction the respective Ca phase contributes to the total precursor. Therefore, and despite the elaborate synthesis mostly required to obtain Sr-substituted $\mathrm{CaP}$ phases which are often not commercially available, such phases can easily be used to introduce varying amounts of $\mathrm{Sr}$ into CPC. For example, the cement forming reaction based on the hydrolysis of $\alpha$-TCP into HA upon mixing with aqueous $\mathrm{Na}_{2} \mathrm{HPO}_{4}$ results in SrHA when $\alpha$-TCP is substituted by $\mathrm{Sr}-\alpha$-TCP although a reduced reactivity was found for $\mathrm{Sr}-\alpha-\mathrm{TCP}$ synthesised at high temperatures. ${ }^{73}$ In a more complex system based on ACP and DCPD, Sr-substituted ACP (SrACP) prepared by gradual replacement of $\mathrm{Ca}\left(\mathrm{NO}_{3}\right)_{2}$ by $\mathrm{Sr}\left(\mathrm{NO}_{3}\right)_{2}$ during ACP precipitation from an aqueous solution allows the preparation of cements setting into SrHA. $^{89}$ Similarly, SrACP prepared from DCPA, calcium hydroxide and $\mathrm{SrCO}_{3}$ via a dry mechanochemical approach was employed as a $\mathrm{Sr}$ source to obtain cements with $\mathrm{Sr} /(\mathrm{Sr}+\mathrm{Ca})$ ratios between 0.025 and 0.2 . Although $\mathrm{SrCO}_{3}$ residues were detected in the set cement at early time points, ongoing hydration led to a decrease in $\mathrm{SrCO}_{3}$ content and substitution of $\mathrm{Sr}^{2+}$-ions in the apatite matrix. ${ }^{90}$

Based on a cement liquid containing various concentrations of $\mathrm{SrCl}_{2}$, cements setting into monophasic Sr-containing apatite can be prepared from $\alpha$-TCP ${ }^{93}$ and $\alpha$-TCP/gelatin ${ }^{75}$ as well as DCPA/ $\mathrm{CaCO}_{3}$ precursor powders. ${ }^{85}$ Due to the solubility of $\mathrm{SrCl}_{2}$ and the limited liquid to powder ratio (l/p) a maximum of $6 \mathrm{wt} \%$ strontium content could be achieved by the second method. During immersion in water, this cement was shown to release around $80 \%$ of the contained strontium within 21 days, indicating a higher solubility of the poorly crystalline, Sr-substituted apatite cement matrix formed during setting. ${ }^{85}$ Similarly, when strontium nitrate was mixed into the liquid phase of an $\alpha$-TCP/TTCP cement the resulting SrHA with up to $4.3 \mathrm{wt} \%$ Sr released more Sr than $\mathrm{Ca} .{ }^{94}$

\subsection{Brushite-forming cements}

Most brushite forming cement formulations comprising strontium are based on the synthesis of Sr-substituted precursor phases (Table 4). One approach is to synthesise Sr-substituted TCP as reactive species. Alkhraisat et $a l^{74}$ prepared $\mathrm{Sr}-\beta$-TCP by sintering $\mathrm{CaHPO}_{4}$ with mixtures of $\mathrm{CaCO}_{3}$ and $\mathrm{SrCO}_{3}$, thus obtaining $\mathrm{Sr}-\beta$-TCP with molar $\mathrm{Sr} /(\mathrm{Sr}+\mathrm{Ca})$ ratios between 0 and 0.33. These were used in a hydraulically setting cement upon mixing with an equimolar amount of MCPM. Lattice parameters of the setting product brushite indicated a substitution of $\mathrm{Ca}^{2+}$ by $\mathrm{Sr}^{2+}$ ions in the set cement. After a small initial burst, a constant release of Sr-ions from the cements was found during immersion in water, releasing up to $2.3 \mathrm{mg}$ strontium per $\mathrm{g}$ cement within 15 days. However, no impact of the Sr-modification on the mechanical properties was found. Another Sr-substituted CPC setting to brushite based on $\alpha$-TCP was described by Pina et al. ${ }^{95,96}$ Firstly, Sr- $\beta$-TCP was synthesised via
Table 4 Selected Sr-containing cement formulations setting into brushite

\begin{tabular}{|c|c|c|c|c|}
\hline Sr-source & $\begin{array}{l}\text { Solid/ } \\
\text { liquid }\end{array}$ & Precursor phases & $\begin{array}{l}\text { Setting } \\
\text { products }\end{array}$ & Ref. \\
\hline Sr- $\beta$-TCP & $\mathrm{s}$ & MCP & Sr-br & 74 \\
\hline Sr- $\alpha-\mathrm{TCP}$ & $\mathrm{s}$ & $\mathrm{Sr}-\alpha-\mathrm{TCP}^{a}$ & Sr-brushite & 95 and 96 \\
\hline $\mathrm{SrCl}_{2}$ & $\mathrm{~s}$ & $\beta$-TCP, MCP, SPP, $\mathrm{SrCl}_{2}$ & Sr-brushite & 56 \\
\hline
\end{tabular}

MCPM: calcium dihydrogen phosphate (monohydrate), SPP: sodium pyrophosphate, Sr- $\alpha$-TCP: strontium-substituted $\alpha$-TCP, Sr- $\beta$-TCP: Srsubstituted $\beta$-TCP. ${ }^{a}$ Cement also contained poly ethylene glycol (PEG) or hydroxyl propyl methylcellulose (HPMC).

aqueous precipitation from calcium nitrate, diammonium hydrogen phosphate and strontium with a $(\mathrm{Ca}+\mathrm{Sr}) / \mathrm{P}$ molar ratio of 1.5 , allowing the precipitation of TCP. The precipitate was subsequently treated thermally at $1500{ }^{\circ} \mathrm{C}$ to obtain Sr- $\alpha$-TCP. To accelerate setting, an aqueous solution of citric acid was used as cement liquid, and poly(ethylene glycol) or hydroxyl propyl methylcellulose was added to enhance washout resistance of the cement paste. The cement set into brushite with $\mathrm{Sr}^{2+}$ ions substituted into the crystal structure. In contrast to the cement described by Alkhraisat et al., this cement exhibited an increased compressive strength compared to a reference material prepared from $\mathrm{Sr}$-free $\alpha$-TCP.

Based on the addition of Sr via the liquid phase, another cement that sets into Sr-brushite is based on the reaction of $\beta$-TCP and MCP in the presence of up to $10 \mathrm{wt} \% \mathrm{SrCl}_{2}$ and traces of sodium pyrophosphate. ${ }^{56}$ In this system high $\mathrm{Sr}$ content led to a slight decrease in the diametral tensile strength of the set cements.

\section{Properties of SrCPC}

\subsection{Cement setting and injectability}

Setting of CPC has been demonstrated to be fundamentally altered by the presence of $\mathrm{Sr}^{2+}$ ions by Guo et al. when $\mathrm{SrHPO}_{4}$ was added to a TTCP/DCPA system. Hydration was retarded significantly, which was attributed to the higher degree of supersaturation that is required to yield Sr-containing apatite crystals. Furthermore, the transformation rate into HA or SrHA, respectively, was reduced in the presence of $\mathrm{Sr}$ albeit this could be partially compensated by higher phosphoric acid content in the cement liquid. ${ }^{84}$ Cements comprising $\mathrm{Sr}$ phases as reactants to form SrHA tend to have prolonged setting times if $\mathrm{SrCO}_{3}$ or DSPA is used as a Sr source. ${ }^{81,83,86} \mathrm{Sr}$ substitution in ACP, on the contrary, induced faster setting in SrACP/DCPA systems. ${ }^{90}$ The setting time of ACP/DCPD cements was reported to significantly increase with the addition of $\mathrm{SrCO}_{3}$ (with at the same time decreasing viscosity of the cement paste). ${ }^{87}$ Hydrolysis of $\alpha$-TCP into CDHA was shown to be decreased in the presence of Sr-containing solution. ${ }^{97}$ The addition of $\mathrm{SrCO}_{3}$ into $\alpha$-TCP based cements merely affected the setting time, which could be due to the fact that $\mathrm{SrCO}_{3}$ did not participate in the setting reaction. ${ }^{86} \mathrm{Sr}$ substituted TCP, whether in the form of $\alpha$-TCP setting to $\mathrm{SrHA}^{73}$ or $\alpha$ - or $\beta$-TCP in brushite forming cements, ${ }^{74}$ was shown to slow down the cement setting, 

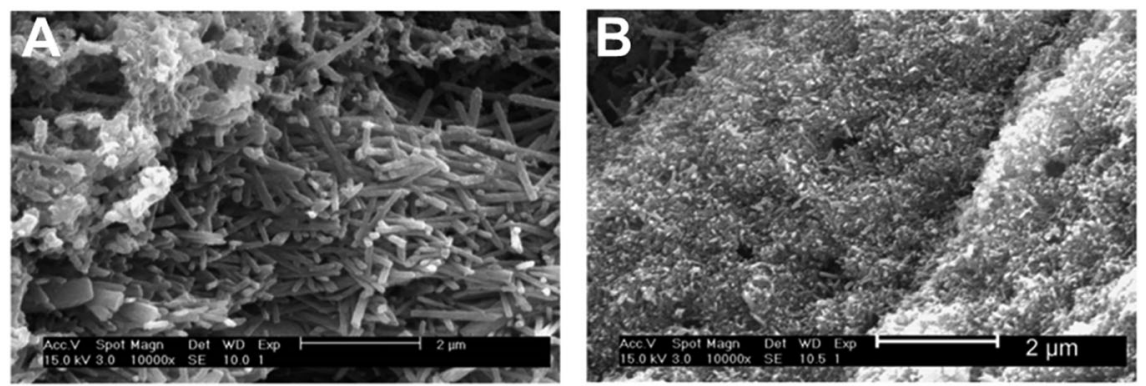

Fig. 4 SEM micrographs of set samples of Sr-free (A) and Sr-containing (B) CPC derived from an ACP/DCPD and ACP/SrCO $3 / D C P D$ precursor, respectively. Reprinted from X. Wang, et al., Influence of a novel radiopacifier on the properties of an injectable calcium phosphate cement, Acta Biomater., 2007, 3(5), 757-763, with permission from Elsevier.

although Pina et al. stated that lattice distortion caused by $\mathrm{Sr}$ substitution enhanced TCP reactivity and did not hinder the conversion of brushite into apatite. ${ }^{95}$

In most cases, the retarding effect of $\mathrm{Sr}$ on the nucleation and crystal growth of apatite results in the formation of much smaller crystals during cement setting. ${ }^{81,86,87,90}$ This is illustrated in Fig. 4 , where smaller crystals are visible after the setting of an Sr-containing, ACP/DCPD-based cement comprising $\mathrm{SrCO}_{3}$ as Sr source. However, some studies either reported no visible differences in the microstructure of the set cements ${ }^{83}$ or at least partially attributed differences in the crystal size to variations in milling parameters during precursor preparation. ${ }^{86}$

Since bone defect treatment via minimally invasive surgical techniques (e.g. in spinal surgery or in order to reinforce osteoporotic bones) has gained considerable attention over the last few years, controlled injectability of both apatite and brushite cements is of interest. ${ }^{98,99}$ Besides powder-to-liquidratio, particle size distribution (controlled by precursor milling time) and organic additives like poly(ethylene glycol) or methylcellulose, ion substitution also affects cement setting and thus injectability ${ }^{96}$ By enhancing the reactivity of $\alpha$-TCP strontium shortens the setting time and thus impairs the injectability of brushite-forming cements based on $\mathrm{Sr}-\alpha$-TCP. ${ }^{96}$ In contrast, $\mathrm{SrCO}_{3}$-laden apatite cements were found to gain injectability with increasing $\mathrm{Sr}$ content due to a decrease in the viscosity of the cement paste. ${ }^{87}$ However, since injectability is also a function of precursor particle size (and size distribution) no general conclusions can be drawn when comparing different studies.

\subsection{Degradation and strontium-ion release}

Degradation of CPC describes the physico-chemical dissolution of the set cements in aqueous environments and is usually quantified by the release of $\mathrm{Ca}^{2+}$ and phosphate ions. Obviously, this process is controlled by the solubility of the cement components (Table 2), but also by parameters like porosity, surface roughness and area as well as material fragmentation. In general, brushite degrades much faster than hydroxyapatite. Depending on the experimental setup, precipitation of CaP crystals from $\mathrm{Ca}$ and phosphate containing immersion liquids can even lead to a virtually negative degradation rate, making it difficult to compare the effects of $\mathrm{Sr}$ modification on degradation in different studies. There is, however, general consensus that lattice expansion induced by the larger $\mathrm{Sr}^{2+}$ ions upon integration in the apatite lattice increases solubility, and consequently higher degradation was demonstrated for SrHA and SrHA forming cements. ${ }^{54,55,93,100}$

There are two mechanisms that can contribute to the release of $\mathrm{Sr}^{2+}$ from a SrCPC. One is the diffusion of $\mathrm{Sr}^{2+}$ from soluble phases in the cement matrix via micropores in the cement caused by the cement liquid, and the second is the physicochemical dissolution of the cement matrix itself. During immersion in large volumes of $\mathrm{Ca}^{2+}$ and $\mathrm{Sr}^{2+}$ free buffer solution (sink conditions), $\mathrm{Sr}$ modification by the addition of solid $\mathrm{SrCO}_{3}$ led to a reduced $\mathrm{Ca}^{2+}$ release in a system that set into a $\mathrm{SrCO}_{3}$-containing, biphasic HA matrix. ${ }^{85}$ Interestingly, Sr introduction into the same cement system via the liquid phase, resulting in a monophasic SrHA matrix, had the opposite effect on $\mathrm{Ca}^{2+}$ release and the $\mathrm{Ca}^{2+}$ release increased compared to the Sr-free control cement. $\mathrm{Sr}^{2+}$, on the other hand, was released to a greater extent from the biphasic cement containing $\mathrm{SrCO}_{3}$ clusters, where $\sim 80 \%$ of the initially contained $\mathrm{Sr}$ was released within 21 days of immersion in water. ${ }^{85}$ The latter effect was also found in an $\alpha$-TCP-based cement system, where cumulative $\mathrm{Sr}^{2+}$ release from a set biphasic $\mathrm{HA} / \mathrm{SrCO}_{3}$ bulk cement did account for only $1.5 \%$ of the initially added Sr but exceeded the release from a monophasic SrHA over 21 days in salt buffer solution. ${ }^{85,86}$ It can be hypothesized that this difference was due to $\mathrm{Sr}^{2+}$ release via dissolution of $\mathrm{SrCO}_{3}$ crystals on the one hand and either diffusion-controlled or degradation-associated $\mathrm{Sr}$ release on the other. In a diffusion-controlled system, a depletion of $\mathrm{Sr}$ at the sample surface should occur, and leaching of $\mathrm{Sr}^{2+}$ from the sample surface was shown for monophasic SrHA cements. ${ }^{85,86}$ In $\mathrm{SrCO}_{3} / \mathrm{HA}$ cements, a decrease of Sr-concentration at the surface of samples immersed in liquid for 35 days was also present and was traceable even further into the bulk cement, suggesting that diffusion can be a limiting factor also in biphasic cements. ${ }^{86}$ For monophasic SrHA cements prepared using a $\mathrm{Sr}\left(\mathrm{NO}_{3}\right)_{2}$ solution, Leroux et al. proposed a two-stage degradation mechanism, comprising an initial phase where $\mathrm{Sr}^{2+}$ release exceeds $\mathrm{Ca}^{2+}$ release due to the dissolution of strontium nitrate traces in the set cement, followed by the congruent release of $\mathrm{Sr}^{2+}$ and $\mathrm{Ca}^{2+}$ according to the ratio contained in the cement during bulk dissolution. Still, only 2 and $4 \mathrm{wt} \%$ of the contained $\mathrm{Ca}$ and Sr, respectively, were released within one month. ${ }^{94}$ 
Although ion release and degradation can more easily be studied in ion-free buffer solutions, more complex immersion media are required to obtain results comparable to the in vitro (or in vivo) situation. Typical for $\alpha$-TCP-based materials is a slight acidification and a depletion of $\mathrm{Ca}^{2+}$ concentration in the immersion medium that arises from the presence of CDHA and the progressive formation of apatite crystals. ${ }^{101,102}$ Since material-mediated Ca depletion can have significant impact on the cellular response, ${ }^{103,104}$ it is important to note that Sr modification can, in some systems, alter this effect. For an $\alpha$-TCP/DCPA $/ \mathrm{CaCO}_{3} / \mathrm{HA}$-based apatite cement immersed in alpha minimum essential cell culture medium $(\alpha \mathrm{MEM}) \mathrm{Ca}^{2+}$ concentration was shown to drop from $1.8 \mathrm{mM}$ to $\sim 0.5 \mathrm{mM}$ and remain low over 21 days despite a regular medium change. Strontium modification, either by addition of $\mathrm{SrCO}_{3}$ crystals or substitution of $\mathrm{CaCO}_{3}$ by $\mathrm{SrCO}_{3}$ in the precursor, resulted in a significant reduction of Ca depletion. Sr was, at the same time, released in higher doses from monophasic SrHA forming cements, resulting in concentrations of 0.05-0.1 mM compared to $0.025-0.05 \mathrm{mM}$ for $\mathrm{SrCO}_{3} / \mathrm{HA}$ biphasic cements. ${ }^{105}$

For brushite-forming cements prepared from $\mathrm{Sr}$ substituted $\beta$-TCP a high, zero-order release of $\mathrm{Sr}$ was found during immersion in water. Up to $2.3 \mathrm{mg} \mathrm{g}^{-1} \mathrm{Sr}$ was released, and the kinetics of $\mathrm{Sr}$ release resembled the one measured for $\mathrm{Ca}$, indicating that $\mathrm{Sr}$ was released by bulk erosion. ${ }^{74}$ In an approach where $\mathrm{Sr}$ was introduced into the cement via the liquid phase an increase in solubility with increasing Sr-content was described. ${ }^{56}$

It is obvious that degradation and thus $\mathrm{Sr}^{2+}$ release differ from any laboratory setup as soon as a SrCPC is implanted into a tissue defect. Besides the complexity of body fluids compared to any of the buffer solutions described above, diffusion processes within the tissue as well as (cell-driven) active ion transport occur. Still several in vivo studies demonstrated an increased degradation of SrCPC compared to the respective Sr-free control groups and thus confirmed the above findings. ${ }^{106,107}$ However, $\mathrm{Sr}^{2+}$ release did in no case result in an increase of serum strontium levels to concentrations comparable to strontium ranelate treatment, suggesting that the released $\mathrm{Sr}^{2+}$ is accumulated in the surrounding bone. ${ }^{91}$

\subsection{Mechanical characteristics of SrCPC}

As all inorganic cements and ceramics, CPC in general exhibit brittle fracture behaviour. Compared to natural bone (cancellous bone: 5-15 MPa and 0.26-0.90 GPa, cortical bone: 133-193 MPa and 17-25 GPa compressive strength and compression modulus, respectively) $)^{1,108}$ most CPC possess poor mechanical strength and thus are mainly intended to be used in non-loadbearing situations. Brushite cements tend to have a lower compressive strength $(10-60 \mathrm{MPa})^{109-111}$ than hydroxyapatite forming ones (up to $75 \mathrm{MPa}$ ), ${ }^{109,112}$ depending mainly on the phase composition of the set cement as well as on the respective porosity. ${ }^{112}$

In SrCPC, contradicting results have been found regarding mechanical characteristics that are summarized in Table 5. It is important to note that the different preparation routes and properties of the set samples, such as porosity, do not allow direct comparison of the mechanical characteristics. In general, the strength of the cements increases within the first days to weeks as hydration proceeds. In most cements setting into monophasic SrHA, strontium modification either increased the compressive strength ${ }^{83,86,90}$ or had no significant effect on the mechanical characteristics. ${ }^{81}$ Nevertheless, one study reported a decrease in the compressive strength of Sr- $\alpha$-TCP cements compared to Sr-free control. ${ }^{73}$ This was attributed to a decreased reactivity of the precursor that was derived from the high sintering temperature during Sr- $\alpha$-TCP synthesis which caused a larger crystal size and therefore slower dissolution speed which was also obvious from the prolonged setting time. To explain the higher strength of most SrHA cements based on multi-component precursors, Yu et al. suggest an increase in Ca $2 p$ and $P 2 p$ binding strength in the Sr-substituted apatite lattice as measured by XPS. ${ }^{90}$ Other parameters in discussion are the occurrence of crystal defects and the inhibitory effect of Sr on the

Table 5 Properties of set SrCPC

\begin{tabular}{|c|c|c|c|c|c|}
\hline $\begin{array}{l}\text { Setting } \\
\text { product }\end{array}$ & $\begin{array}{l}\text { Porosity } \\
\text { [vol\%] }\end{array}$ & $\begin{array}{l}\text { Compressive } \\
\text { strength }^{a}[\mathrm{MPa}]\end{array}$ & $\begin{array}{l}\text { Initial setting } \\
\text { time [min] }\end{array}$ & $\begin{array}{l}\text { Final setting } \\
\text { time }[\mathrm{min}]\end{array}$ & Ref. \\
\hline SrHA (m) & $\mathrm{n} / \mathrm{a}$ & $\sim 66(+)$ & $(+)$ & $(+)$ & 83 \\
\hline SrHA (m) & $52(-)$ & $\mathrm{n} / \mathrm{a}$ & $\mathrm{n} / \mathrm{a}$ & $\mathrm{n} / \mathrm{a}$ & 85 \\
\hline SrHA (m) & $<5$ & $12-13(/)$ & $6-34(-)$ & $13-82(-)$ & 81 \\
\hline SrHA (m) & $\mathrm{n} / \mathrm{a}$ & $\sim 10(-)$ & $(-)$ & $(-)$ & 73 \\
\hline SrHA (m) & $56-58$ & $63-74(+)$ & $21-28(+)$ & $37-52(+)$ & 90 \\
\hline SrHA (m) & $30-42(+)$ & $\sim 53(+)$ & $\sim 13 \min (+)$ & $\sim 33 \min (+)$ & 86 \\
\hline SrHA (m) & $\mathrm{n} / \mathrm{a}$ & $10-20(+)$ & $11-17(+)$ & $17-21(+)$ & 88 \\
\hline SrCDHA (m) & $38-47(+)$ & $4-13(+/-)$ & $4-20(+)$ & $9-50(+)$ & 75 \\
\hline $\mathrm{HA} / \mathrm{SrCO}_{3}$ (b) & $(+)$ & $40(+)$ & $\sim 30-40(+)$ & $\sim 45-55(+)$ & 87 \\
\hline $\mathrm{HA} / \mathrm{SrCO}_{3}(\mathrm{~b})$ & $49(-)$ & $\mathrm{n} / \mathrm{a}$ & $\mathrm{n} / \mathrm{a}$ & $\mathrm{n} / \mathrm{a}$ & 85 \\
\hline $\mathrm{HA} / \mathrm{SrCO}_{3}$ (b) & $26-40(-)$ & $\sim 15(-)$ & $\sim 7 \min (/)$ & $\sim 26 \min (/)$ & 86 \\
\hline Sr-brushite (m) & $\sim 50(/)$ & $\sim 5-6(/)$ & $2-5(+)$ & $\mathrm{n} / \mathrm{a}$ & 74 \\
\hline Sr-brushite (m) & $\mathrm{n} / \mathrm{a}$ & $\sim 22(+)$ & $3-7(+)$ & $\mathrm{n} / \mathrm{a}$ & 95 \\
\hline
\end{tabular}

$(+)$ increased, (/) unaffected, $(-)$ decreased (against Sr free reference). $\mathrm{m}=$ monophasic, $\mathrm{b}=$ biphasic cement matrix after setting. ${ }^{a}$ For series with different $\mathrm{Sr} /(\mathrm{Sr}+\mathrm{Ca})$ ratios the maximum strength is shown. 
apatite depositing rate. $^{83}$ In their TTCP/DCPA/DSPA cement system, Guo et al. described a non-linear influence of Sr content on the mechanical properties: while an optimum composition was found at a $\mathrm{Sr} /(\mathrm{Sr}+\mathrm{Ca})$ ratio of 0.05 with an increase of compressive strength up to $66 \mathrm{MPa}$ compared to $\sim 50 \mathrm{MPa}$ for the $\mathrm{Sr}$-free reference cement, higher $\mathrm{Sr}$ content resulted in a reduced compressive strength. ${ }^{83,84}$ A comparable optimum was described for DCPD-based cements where $\mathrm{SrCO}_{3}$ replaced the second precursor component, $\mathrm{CaO} .{ }^{88}$ Here, up to $1.5 \%$ molar fraction of $\mathrm{SrCO}_{3}$ increased the compressive strength of the set cement from $\sim 7$ to $\sim 20 \mathrm{MPa}$. Again, higher substitution resulted in decreased strength values. In contrast Kuang et al. found no effect on the mechanical properties for the same cement system with partial or complete substitution of DCPA by DSPA $(\mathrm{Sr} /(\mathrm{Sr}+\mathrm{Ca})=0-0.2)$, although the overall compressive strength was significantly lower $(\sim 12 \mathrm{MPa}$ after 28 days $) .{ }^{81}$ Still, in this cement a polymer component had been added to the cement liquid which might have interfered with the setting process. Full replacement of DCPA by DSPA and $\mathrm{CaCO}_{3}$ by $\mathrm{SrCO}_{3}$, on the other hand, reduced the compressive strength of $\alpha$-TCP/DCPA $/ \mathrm{CaCO}_{3} / \mathrm{HA}$ cements. ${ }^{91}$ In contrast, in another monophasic system, up to $8.37 \mathrm{wt} \%$ strontium in SrHA derived from an $\alpha-\mathrm{TCP} / \mathrm{DCPA} / \mathrm{HA} / \mathrm{CaCO}_{3}$ precursor by substitution of $\mathrm{CaCO}_{3}$ by $\mathrm{SrCO}_{3}$ increased the compressive strength significantly from 32 to $53 \mathrm{MPa} .{ }^{86}$ In a SrACP/DCPD cement higher compressive strength values were found for $\mathrm{Sr} /(\mathrm{Sr}+\mathrm{Ca})$ ratios between 0.025 and 0.2 (up to $75 \mathrm{MPa}$ after 10 days) compared to Sr-free reference cement. Although residues of $\mathrm{SrCO}_{3}$ were present in the cement at early time points, hydration was shown to lead to a decrease in $\mathrm{SrCO}_{3}$ content and the integration of $\mathrm{Sr}$ in the apatite matrix. ${ }^{90} \mathrm{Sr}$ modification via the cement liquid also results in the formation of SrHA; however, only modest impact on the mechanical properties was described by Panzavolta et al., where $1 \mathrm{wt} \%$ substitution increased compressive strength, whilst higher substitution resulted in decreased strength. ${ }^{75}$

In cement systems setting into $\mathrm{HA}-\mathrm{SrCO}_{3}$ composite matrices, a decrease of mechanical strength compared to unmodified cement control samples was reported. This was explained by the low binding strength of $\mathrm{SrCO}_{3}$ residues and the surrounding apatite matrix and the role of these crystals as crack initiators under compression loading. ${ }^{86}$ Wang et al. postulated a small amount of $\mathrm{Sr}$ substitution into the $\mathrm{HA}$ lattice from intermixed $\mathrm{SrCO}_{3}$ particles and thus a small increase in compressive strength, whilst at higher $\mathrm{SrCO}_{3}$ loading ratios compressive strength also decreased. ${ }^{87}$ In contrast to residual $\mathrm{SrCO}_{3}$ clusters with poorly defined morphology, addition of SrHA whiskers was shown to significantly increase the strength of set cements at concentrations of 2.5 and $5 \mathrm{wt} \%$. This result was attributed to the entanglement of the elongated whiskers, although at higher contents (10 wt\%) a decrease of compressive strength was found. ${ }^{92}$

In brushite forming cements based on Sr- $\beta$-TCP the presence of Sr did merely affect the compressive strength, as well as porosity, although a tendency to set into monetite instead of brushite was found at $\mathrm{Sr}$ contents up to 20 at $\%{ }^{74}$ In contrast, Pina et al. found elevated compressive strength in Sr- $\alpha$-TCP

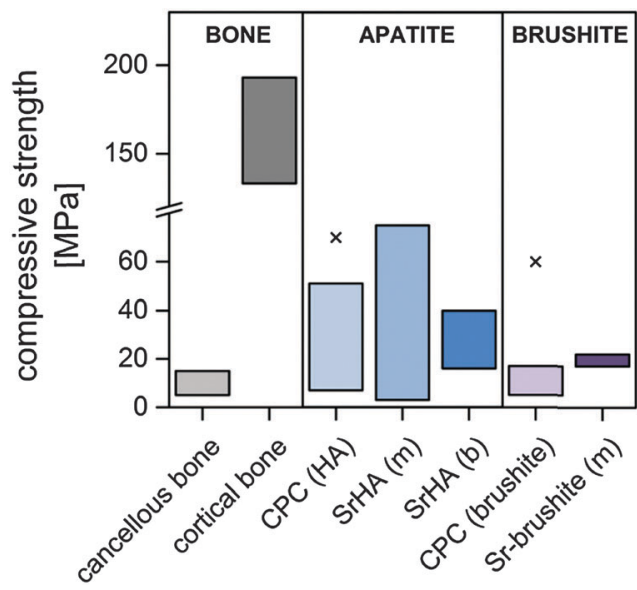

Fig. 5 Comparison of compressive strength values of natural bone, different $\mathrm{SrCPC}$ ( $\mathrm{m}$ : mono- and b: biphasic setting product) and their respective $\mathrm{Sr}$ free reference materials. " $x$ " indicates the highest strength values of other HA and brushite cements described in the literature. ${ }^{1,73-75,81,83,85-88,90,95,108}$

based cements, and attributed this to the reduced conversion of the precursor in the mechanically weaker setting product brushite. However, the high solubility of brushite leads to a fast degradation of the cement which resulted in a decrease of strength over time. ${ }^{95}$

In general, the mono- or biphasic nature of the setting product of the respective cement system seems to be a key parameter for the mechanical properties: while the gain in strength caused by crystal lattice deformation associated with Sr substitution can lead to a certain increase in both apatite and brushite cement strength the presence of secondary clusters impairs the mechanical integrity of the set cement (Fig. 5).

\subsection{Radiopacity}

Apart from the therapeutic benefits of $\mathrm{Sr}$ modification and possible improvement of mechanical properties, another rationale to introduce Sr-phases into $\mathrm{CaP}$ bone cements is their increasing effect on the adsorption of X-rays. This is of interest since high radiopacity is required to monitor the positioning of injectable cements during surgery and follow-up imaging. Various species such as $\mathrm{SrCl}_{2}, \mathrm{SrCO}_{3}, \mathrm{SrBr}_{2}$, and $\mathrm{SrF}_{2}$ have been evaluated to modify $\mathrm{CPC}^{86-88,90,113,114}$ or calcium-aluminiumphosphate cements $^{115}$ for that purpose. In most cases an increase of radiopacity with $\mathrm{Sr}$ content was shown. For example, Wang et al. demonstrated that $4-20 \%$ Sr substitution allows one to distinguish SrCPC from bone samples with the same thickness in radiographic images (Fig. 6) ${ }^{87}$ When comparing cements setting to $\mathrm{SrHA}$ and $\mathrm{SrCO}_{3} / \mathrm{HA}$ the latter showed less increase of radiopacity at similar $\mathrm{Sr}$ contents which was attributed to the low resolution of the radiographic imaging that could not correctly represent small local contrast variations as to be expected in biphasic matrices. ${ }^{86}$

\subsection{Biological properties based on cell culture studies}

Only a few data have been published on the in vitro characteristics of Sr-modified CPC. In general, Sr modification does not 


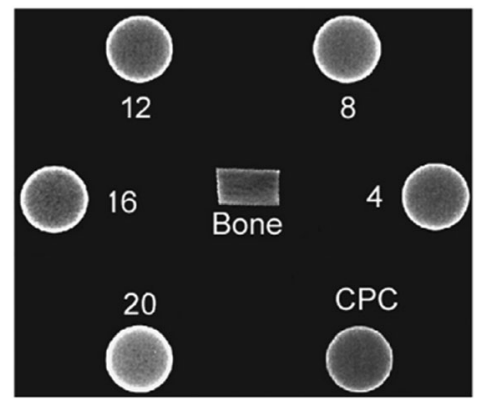

Fig. 6 Radiograph of cortical bone and CPC samples (5 $\mathrm{mm}$ thickness) with 4-20\% Sr content. Reprinted from X. Wang, et al., Influence of a novel radiopacifier on the properties of an injectable calcium phosphate cement, Acta Biomater., 2007, 3(5), 757-763, with permission from Elsevier.

induce cytotoxicity. In cell cultures treated with extracts of SrHA, ${ }^{81,86}$ biphasic $\mathrm{HA} / \mathrm{SrCO}_{3}{ }^{86}$ and SrHA-whisker reinforced cements, ${ }^{92}$ a positive effect of the $\mathrm{Sr}$ doping and/or the $\mathrm{Sr}^{2+}$ released from the cements was found on cell proliferation and osteogenic differentiation. It was further stated that the decreased tendency of SrCPC to cause medium $\mathrm{Ca}^{2+}$ depletion as well as a smaller variation in the $\mathrm{pH}$ during SrCPC setting may contribute to these findings. ${ }^{86}$ Only one study described a slight cytotoxic effect of highly concentrated SrHA extracts on the murine connective tissue cell line L929. ${ }^{83}$ Table 6 shows an overview of the in vitro effects of SrCPC. For example, Tadier et al. found a higher proliferation rate of osteoprogenitor cells on biphasic $\mathrm{SrCO}_{3} / \mathrm{HA}$ compared to monophasic SrHA cements that were derived from a $\mathrm{DCPD} / \mathrm{CaCO}_{3} / \mathrm{SrCO}_{3}$ precursor. However, at an mRNA level there was no difference in osteogenic differentiation. ${ }^{85}$ In contrast two different routes of Sr modification based on an $\alpha$-TCP precursor, setting into SrHA and $\mathrm{SrCO}_{3} / \mathrm{HA}$, respectively, were both shown to stimulate proliferation and osteogenic differentiation of primary human mesenchymal stem cells. ${ }^{105}$ Interestingly, proliferation was generally more enhanced in samples kept under basal cell culture conditions, whilst cells cultured in medium supplemented with osteogenic additives showed higher proliferation on monophasic SrHA cement matrices. This indicates different susceptibilities of cells towards Sr depending on their stage of differentiation. No cytotoxicity (using MG63 osteoblast-like cells in an indirect culture setup) but an enhanced proliferation and osteogenic differentiation in a direct setup using MC3T3-E1 murine pre-osteoblasts were found for TTCP/DCPA/DSPA based SrHA cements. A comparable cell morphology was found on SrCPC and Sr free controls. ${ }^{107}$ Similarly, enhanced proliferation and osteogenic differentiation were observed for MG63 osteoblasts cultured on $\alpha$-TCP/gelatine/DCPD cements where $\mathrm{Sr}$ was introduced via the liquid phase. ${ }^{75}$ Since the stimulatory effect of Sr modification was found in indirect cell culture setups as well as in direct contact cultures, it can be hypothesised that different aspects contribute to the positive cell reaction: release of $\mathrm{Sr}^{2+}$ from the cement, altered ionic interaction of the cement and the cell culture medium, resulting in e.g. reduced $\mathrm{Ca}^{2+}$ depletion and reduced acidification of the medium. ${ }^{85,105}$

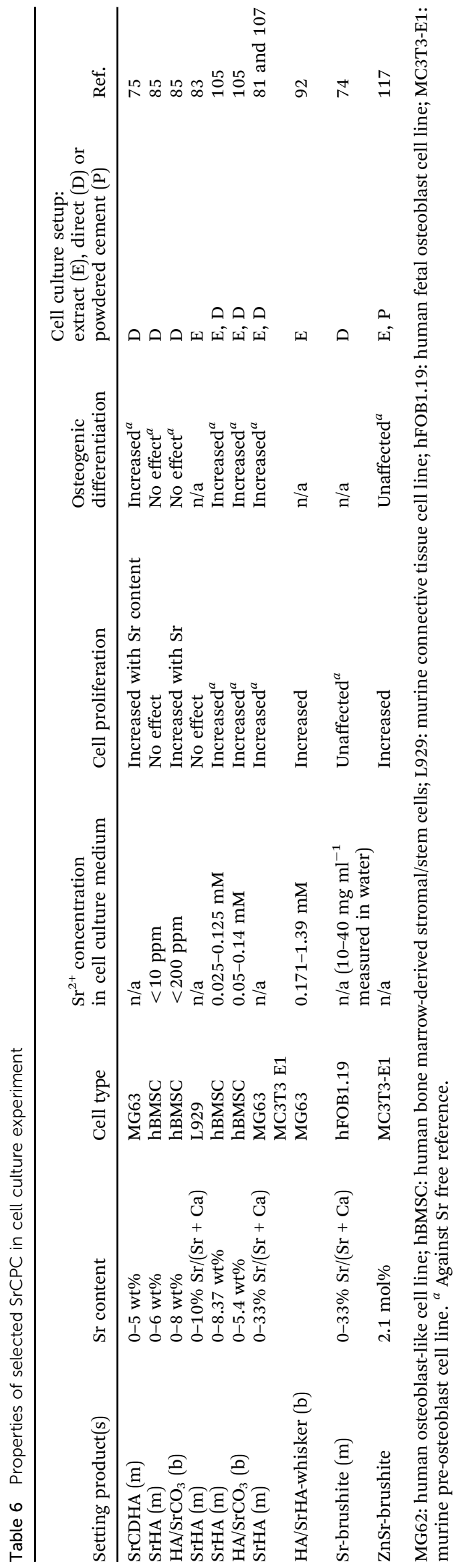


In $\mathrm{Sr}$ containing brushite cements prepared from Sr- $\beta$-TCP and MCPM, no distinct influence of $\mathrm{Sr}$ content on proliferation and metabolic activity of human osteoblasts was found in a direct setup. The cement released up to $40 \mathrm{ppm}(0.56 \mathrm{mM})$ strontium. ${ }^{74}$ However, this release test was performed during immersion in water, and might not correctly represent the situation in cell culture conditions, as it is known that e.g. protein content of immersion solutions can limit ion release. ${ }^{116}$ In comparison to $\mathrm{Zn}$-doped brushite cements additional doping with Sr was shown to increase the metabolic activity of murine osteoblast precursors. ${ }^{117}$ Therefore it can be concluded that the beneficial effects of $\mathrm{Sr}$ on both proliferation and differentiation of osteogenic cells were confirmed for SrCPC.

Until today, to the best of our knowledge no data have been published on the osteoclastic resorption of $\mathrm{Sr}$ containing CPC in vitro. Still, the anti-resorptive effects of $\mathrm{Sr}$ incorporated in hydroxyapatite have been demonstrated by Yang et al. using mineralised films prepared by precipitation from $\mathrm{Ca}$ and $\mathrm{Sr}$ containing liquids, that somewhat resemble the characteristics of set CPCs: osteoclastic activity, by means of resorption pit area, was significantly decreased in the presence of different $\mathrm{Sr}^{2+}$ concentrations while osteoblast proliferation increased in a Sr dose-dependent manner and osteoblast activity remained unaffected. ${ }^{118}$

\subsection{In vivo studies on strontium-containing cements}

Although the stimulating effect of systemically administered strontium ranelate on bone formation has been questioned recently, ${ }^{119}$ evidence exists that the local release of $\mathrm{Sr}^{2+}$ into a specific bone defect can support defect healing. One of the first studies using a Sr-containing bone cement in vivo was published by Ni et al. in 2006, although SrHA was only used as a filler in a resin-based cement. ${ }^{120}$ However, promising results were obtained, with the Sr-laden cement exhibiting an increased bonding strength to bone compared to the Sr-free PMMA cement control group. Positive results for new bone formation at the bone-implant area of SrHA-containing polymeric cements were also described by others. ${ }^{121-124}$ Wong et al. pointed out that neither inflammatory response nor necrotic reactions or fibrous encapsulation that occurred in the PMMA control group were found in the SrHA-PMMA cement group. ${ }^{123}$

In vivo studies focussing on SrCPC of different compositions are summarised in Table 7. In an intramuscular implantation study, Dagang Guo et al. demonstrated an increase of material degradation with increasing $\mathrm{Sr} /(\mathrm{Ca}+\mathrm{Sr})$ ratio using pre-set cylinders prepared from a TTCP/DCPA/DSPA cement with up to $10 \%$ strontium substitution. ${ }^{106}$ This was confirmed in bone contact when the same material was implanted into a femoral drill hole defect. Furthermore, a tight bond of newly formed bone was found at the interface between the cement and the host bone. Similarly, Kuang et al. implanted pre-set TTCP/ DCPA/DSPA based SrHA cement cylinders in a metaphyseal drill-hole defect model in rats. ${ }^{107}$ Again, enhanced degradation was found for SrHA compared to Sr-free reference after 32 weeks; however, it remains unclear whether this was caused by higher physico-chemical dissolution or cellular resorption. Early endochondral ossification after 2 weeks and higher new bone deposition (4 weeks post operation) indicated an enhanced osteo-regenerative potential of the SrHA cement, although only a small number of animals was used. In another study, it was shown that a SrHA cement accelerated graft healing in anterior cruciate ligament reconstruction using allogenic ligament grafts impregnated with a Sr-containing cement in comparison to Sr-free control. ${ }^{125}$

Table 7 Summary of animal studies on SrCPC

\begin{tabular}{lll}
\hline Cement type & Animal model & Type of defect \\
\hline SrHA (pre-set) & $\begin{array}{l}\text { 8-10 month old } \\
\text { New Zealand rabbits }\end{array}$ & $\begin{array}{l}\text { Intramuscular } \\
(\text { m. sacrospinalis })\end{array}$ \\
& & Drill hole $(2.2 \mathrm{~mm})$ \\
SrHA (pre-set) & $\begin{array}{l}3 \text { month old Sprague- } \\
\text { Dawley rats }\end{array}$ & $\begin{array}{l}\text { Drill hole }(2.5 \times 4 \mathrm{~mm}) \\
\text { metaphyseal }\end{array}$
\end{tabular}

n/a ( $\alpha$-TCP based) 10 week old Sprague- Drill hole $(2 \mathrm{~mm})$ Dawley rats ( + ) 2 metaphyseal months after OVX, OPen

SrHA 10 week old Sprague- Metaphyseal, $4 \mathrm{~mm}$ wedgeDawley rats ( $\$$ ), 12 weeks after OVX, D, OPen shaped, bridged with an osteosynthesis plate

$$
\begin{aligned}
& \text { Results } \\
& \text { Cement degradation increased with the } \mathrm{Sr} /(\mathrm{Sr}+\mathrm{Ca}) \text { molar } \\
& \text { ratio during intramuscular implantation for } 24 \text { weeks, } \\
& \text { reaching approx. } 50 \% \text { in the } 10 \% \text { substituted group. } \\
& \text { After } 4-24 \text { weeks degradation increased with Sr-content } \\
& \text { (up to } 10 \% \text { ). Good integration of } 10 \% \mathrm{SrCPC} \text { was found. Sr was } \\
& \text { located in the newly mineralised surrounding tissue. } \\
& \text { Enhanced endochondral ossification was found in the } 10 \% \\
& \text { Sr-CPC group after } 2 \text { weeks, whilst after } 4-16 \text { weeks post- } \\
& \text { operation progressive osteo-conduction was found in both } \\
& \text { groups. } \\
& \text { After } 1,3 \text { and } 6 \text { months, SrCPC exhibited increased fragmentation. } \\
& \text { Faster osseointegration and increased new bone formation were } \\
& \text { found in the SrCPC group compared to Sr-free reference. } \\
& \text { Fragmentation promoted implant integration. } \\
& \text { After } 6 \text { weeks a significant increase of new bone formation in } \\
& \text { the SrCPC group against CPC and empty defect was found. } \\
& \text { Upregulation of bone-specific markers bone-morphogenic } \\
& \text { protein-2, osteocalcin, osteoprotegerin and alkaline phosphatase; } \\
& \text { increased collagen formation. Sr }{ }^{2+} \text { was found in the newly formed } \\
& \text { bone tissue around the implant. } \\
& \text { After } 1 \text { and } 2 \text { months the highest new bone formation with the } \\
& \text { most pronounced organisation level was found in the SrZn-group } \\
& \text { compared to Sr-free ZnCPC and CDHA cement control (commercial). } \\
& \text { Less osteoclasts were found around SrZnCPC. }
\end{aligned}
$$
Ref.

ZnSr-brushite $\quad$ Pig $(\widehat{o}, n=2)$

Drill hole $\left(3.5 \times 10 \mathrm{~mm}^{3}\right)$

OVX: ovariectomized; D: animals received calcium and phosphate deficient diet; OPen: animals had confirmed pre-implantation osteopenic bone status. 

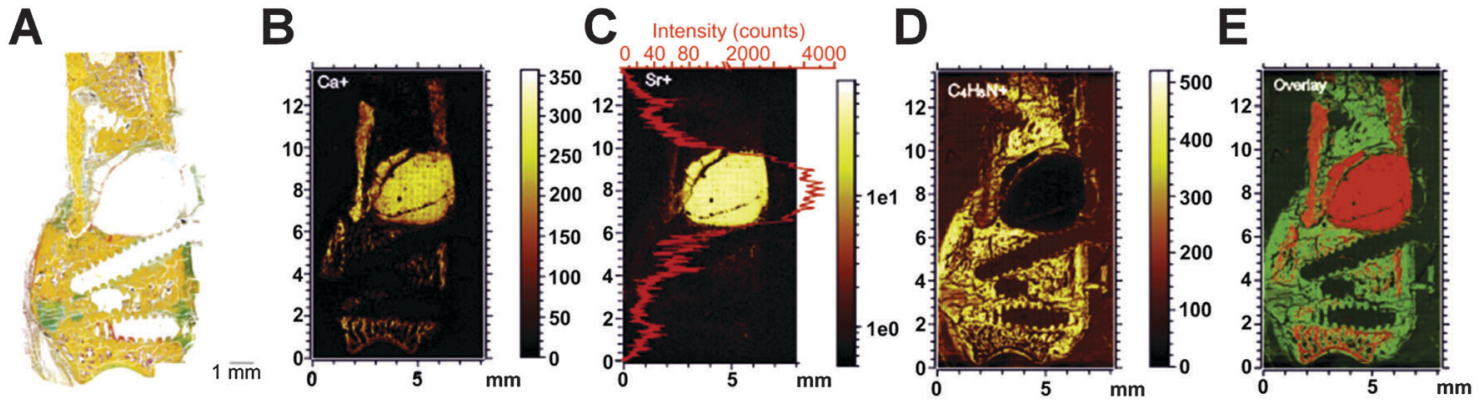

Fig. 7 Histological overview of the implant region where a Sr-modified CPC was implanted into a metaphyseal critical-size defect in the femora of ovariectomized rats (A) and mass distribution of $\mathrm{Ca}^{+}(\mathrm{B}), \mathrm{Sr}^{+}$(C) and $\mathrm{C}_{4} \mathrm{H}_{8} \mathrm{~N}^{+}$(D) and overlay of $\mathrm{Ca}^{+}, \mathrm{Sr}^{+}$and $\mathrm{C}_{4} \mathrm{H}_{8} \mathrm{~N}^{+}(\mathrm{E})$ as measured by ToF-SIMS. Reprinted from U. Thormann, et al., Bone formation induced by strontium modified calcium phosphate cement in critical-size metaphyseal fracture defects in ovariectomized rats, Biomaterials, 2013, 34, 8589-8598, with permission from Elsevier.

To study the effects of Sr-modified CaP intended to positively influence the bone metabolism in osteoporotic bone in vivo, the key issue is to select an appropriate animal model that resembles the human osteoporotic fracture situation. ${ }^{126}$ Baier et al. implanted an $\alpha-\mathrm{TCP} / \mathrm{SDPA} / \mathrm{SrCO}_{3} / \mathrm{HA}$ cement in a metaphyseal drill hole defect in ovariectomized rats in comparison to a $\mathrm{Sr}$ free reference cement. ${ }^{91}$ It is interesting to note that the occurrence of discontinuities within the cement appeared as a key for cement integration into the bone tissue, since new bone formation was found at these sites and was even enhanced in the case of Sr-laden cement. Moreover, BMD measurements revealed a local increase of bone in the cement-treated metaphyseal region, suggesting that $\mathrm{Sr}$ released from the cements led to a local bone-anabolic effect. This is supported by a recent study, where ToF-SIMS imaging was used to visualize Sr-distribution in histological sections of the metaphyseal region of rat femora where a SrHA cement based on $\alpha$-TCP, DCPA, $\mathrm{SrCO}_{3}$ and HA had been implanted to bridge a wedge-shaped critical size defect resembling a typical osteoporotic fracture (Fig. 7). ${ }^{127}$ Furthermore, histomorphometric analysis of bone formation as well as immunohistochemical analysis of bone-related markers confirmed an increased bone formation and remodelling activity in the $\mathrm{Sr}$-HA group.

Only one study focussing on the in vivo properties of Sr-containing brushite cement has been published so far: in a trabecular bone defect in pigs Pina et al. demonstrated positive effects of Sr co-doping of a $\mathrm{Zn}$-containing brushite cement. $\mathrm{Sr}$ doping was found to reduce the osteoclast density at the boneimplant interface and to increase new bone formation. ${ }^{117}$

Although data on the in vivo effects of SrCPC are sparse, published data strongly suggest that Sr doping of CPC positively influences local bone regeneration. In particular animal studies in osteoporotic models revealed promising results towards the utilisation of SrCPC in the clinical treatment of osteoporosis related fractures.

\section{Conclusions}

A variety of approaches towards strontium-substituted calcium phosphate bone cements have been published in the last few years.
Most of them are based on the use of Sr-containing phases that are intermixed with the conventional precursor powder or substitute CaP phases therein, whilst others use the cement liquid to introduce $\mathrm{Sr}^{2+}$ into the cement. The resulting cements can be categorised into those that set into mono- or multiphasic matrices that are characterised by a homogeneous $\mathrm{Sr}$ distribution or contain $\mathrm{Sr}$ rich clusters, respectively. In general, $\mathrm{Sr}$ substituted CPC are characterised by an enhanced degradability both under laboratory conditions and in vivo. Given the differences in the phase composition and porosity of the cements no general conclusion on the effects of Sr modification on the mechanical properties of the set cements can be drawn, but an increased strength has been found in many compositions setting into monophasic SrHA, whereas multi-phasic cements tend to have lower strength. The stimulatory effect of $\mathrm{Sr}^{2+}$ released from the cements has clearly been shown in vitro, although the use of various cell types that may have different susceptibilities to $\mathrm{Sr}^{2+}$ concentrations, varying experimental setups and cement characteristics (e.g. porosity) prohibit general conclusions on the optimal degree of substitution. There remains a need to study the influence of $\mathrm{Sr}$ modification on bone resorbing cells in vitro. However, evidence exists from a few in vivo studies that the potential of $\mathrm{Sr}^{2+}$ to stimulate bone formation can be used to locally enhance new bone formation without systemic side effects. Therefore, strontium modified calcium phosphate bone cements are promising materials that could help to improve clinical outcome in the regeneration of bone defects, in particular in the case of diseased, e.g. osteoporotic, bone.

\section{Acknowledgements}

This work was funded by the German Research Foundation (DFG) as part of the Collaborative Research Centre/Transregio 79 (SFB/TR 79).

\section{References}

1 K. A. Hing, Proc. R. Soc. London, Ser. A, 2004, 362, 2821-2850.

2 J. H. Shepherd, D. V. Shepherd and S. M. Best, J. Mater. Sci.: Mater. Med., 2012, 23, 2335-2347. 
3 S. V. Dorozhkin, J. Mater. Sci., 2007, 42, 1061-1095.

4 L. L. Hench and J. M. Polak, Science, 2002, 295, 1014-1017.

5 A. Ruys, J. Aust. Ceram. Soc., 1993, 29, 71-80.

6 I. R. Gibson, S. M. Best and W. Bonfield, J. Biomed. Mater. Res., 1999, 44, 422-428.

7 Z. Huan and J. Chang, J. Mater. Sci.: Mater. Med., 2009, 20, 833-841.

8 G. Mestres, C. Le Van and M.-P. Ginebra, Acta Biomater., 2012, 8, 1169-1179.

9 A. Bigi, G. Falini, E. Foresti, A. Ripamonti, M. Gazzano and N. Roveri, J. Inorg. Biochem., 1993, 49, 69.

10 Z. Zyman, M. Tkachenko, M. Epple, M. Polyakov and M. Naboka, Materialwiss. Werkstofftech., 2006, 37, 474-477.

11 K. J. Lilley, U. Gbureck, J. C. Knowles, D. F. Farrar and J. E. Barralet, J. Mater. Sci.: Mater. Med., 2005, 16, 455-460.

12 P. Habibovic and J. E. Barralet, Acta Biomater., 2011, 7, 3013-3026.

13 M.-P. Ginebra, C. Canal, M. Espanol, D. Pastorino and E. B. Montufar, Adv. Drug Delivery Rev., 2012, 64, 1090-1110.

14 P. J. Marie, Curr. Opin. Pharmacol., 2005, 5, 633-636.

15 P. S. Nielsen, Bone, 2004, 35, 583-588.

16 Toxicological profile for strontium (no authors given), Strontium CAS\#: 7440-24-6, Department of Health And Human Services, Public Health Service Agency for Toxic Substances and Disease Registry, 2004.

17 O. R. Leeuwenkamp, W. J. van der Vijgh, B. C. Hüsken, P. Lips and J. C. Netelenbos, Calcif. Tissue Int., 1990, 47, 136-141.

18 E. Shorr and A. C. Carter, Bull. Hosp. Jt. Dis., 1952, 13, 59-66.

19 J. McCaslin and F. E. Janes, Proc. Staff Meet. Mayo Clin., 1959, 34, 329-334.

20 S. C. Skoryna, Can. Med. Assoc. J., 1981, 125, 703-712.

21 T. Morohashi, T. Sano, K. Harai and S. Yamada, Jpn. J. Pharmacol., 1995, 68, 153-159.

22 J. Y. Reginster, E. Seeman, M. C. De Vernejoul, S. Adami, J. Compston, C. Phenekos, J. P. Devogelaer, M. D. Curiel, A. Sawicki, S. Goemaere, O. H. Sorensen, D. Felsenberg and P. J. Meunier, J. Clin. Endocrinol. Metab., 2005, 90, 2816-2822.

23 P. J. Meunier, C. Roux, S. Ortolani, M. Diaz-Curiel, J. Compston, P. Marquis, C. Cormier, G. Isaia, J. Badurski, J. D. Wark, J. Collette and J. Y. Reginster, Osteoporosis Int., 2009, 20, 1663-1673.

24 P. J. Marie, Curr. Opin. Rheumatol., 2006, 18, S11-S15.

25 P. J. Marie, Bone, 2007, 40, S5-S8.

26 E. Bonnelye, A. Chabadel, F. Saltel and P. Jurdic, Bone, 2008, 42, 129-138.

27 J. Braux, F. Velard, C. Guillaume, S. Bouthors, E. Jallot, J.-M. Nedelec, D. Laurent-Maquin and P. Laquerrière, Acta Biomater., 2011, 7, 2593-2603.

28 E. Canalis, M. Hott, P. Deloffre, Y. Tsouderos and P. J. Marie, Bone, 1996, 18, 517-523.

29 S. C. Verberckmoes, M. E. De Broe and P. C. D'Haese, Kidney Int., 2003, 64, 534-543.

30 N. Chattopadhyay, S. J. Quinn, O. Kifor, C. Ye and E. M. Brown, Biochem. Pharmacol., 2007, 74, 438-447.
31 P. J. Marie, Bone, 2010, 46, 571-576.

32 F. Yang, D. Yang, J. Tu, Q. Zheng, L. Cai and L. Wang, Stem Cells, 2011, 29, 981-991.

33 S. Peng, X. S. Liu, S. Huang, Z. Li, H. Pan, W. Zhen, K. D. K. Luk, X. E. Guo and W. W. Lu, Bone, 2011, 49, 1290-1298.

34 A. D. Bakker, B. Zandieh-Doulabi and J. Klein-Nulend, Bone, 2013, 53, 112-119.

35 S. Choudhary, P. Halbout, C. Alander, L. Raisz and C. Pilbeam, J. Bone Miner. Res., 2007, 22, 1002-1010.

36 A. S. Hurtel-Lemaire, R. Mentaverri, A. Caudrillier, F. Cournarie, A. Wattel, S. Kamel, E. F. Terwilliger, E. M. Brown and M. Brazier, J. Biol. Chem., 2009, 284, 575-584.

37 R. LeGeros, A. Chohayeb and A. Shulman, J. Dent. Res., 1982, 61, 343.

38 W. Brown and L. Chow, J. Dent. Res., 1983, 62, 672.

39 W. Brown and L. Chow, US RE33221 E, 1990, vol. 33, p. 221.

40 M. Bohner, Injury, 2000, 31, 37-47.

41 F. C. Driessens, J. A. Planell, M. G. Boltong, I. Khairoun and M. P. Ginebra, Proc. Inst. Mech. Eng., Part H, 1998, 212, 427-435.

42 O. Bermúdez, M. G. Boltong, F. C. M. Driessens and J. A. Planell, J. Mater. Sci.: Mater. Med., 1994, 5, 160-163.

43 J. Lacout, E. Mejdoubi and M. Hamad, J. Mater. Sci.: Mater. Med., 1996, 7, 371-374.

44 F. C. M. Driessens, E. A. de Maeyer, E. Fernandez, M. G. Boltong, G. Berger, R. M. Verbeeck, M. P. Ginebra and J. A. Planell, Bioceramics, 1996, 9, 231-234.

45 M. P. Ginebra, E. Fernández, E. A. de Maeyer, R. M. Verbeeck, M. G. Boltong, J. Ginebra, F. C. Driessens and J. A. Planell, J. Dent. Res., 1997, 76, 905-912.

46 D. Knaack, M. E. Goad, M. Aiolova, C. Rey, A. Tofighi, P. Chakravarthy and D. D. Lee, J. Biomed. Mater. Res., 1998, 43, 399-409.

47 L. M. Grover, J. C. Knowles, G. J. P. Fleming and J. E. Barralet, Biomaterials, 2003, 24, 4133-4141.

48 C. D. Friedman, P. D. Costantino, S. Takagi and L. C. Chow, J. Biomed. Mater. Res., 1998, 43, 428-432.

49 S. V. Dorozhkin, Biomatter, 2011, 1, 121-164.

50 E. Fernández, F. J. Gil, M. P. Ginebra, F. C. Driessens, J. A. Planell and S. M. Best, J. Mater. Sci.: Mater. Med., 1999, 10, 169-176.

51 M. A. Aia, J. E. Mathers and R. W. Mooney, J. Chem. Eng. Data, 1964, 9, 335-338.

52 P. Patnaik, Handbook of Inorganic Chemicals, McGraw-Hill Handbooks, McGraw-Hill, 2002.

53 J. Dean and N. Lange, Lange's handbook of chemistry, McGraw-Hill, 1992.

54 J. Christoffersen, M. R. Christoffersen, N. Kolthoff and O. Barenholdt, Bone, 1997, 20, 47-54.

55 H. B. Pan, Z. Y. Li, W. M. Lam, J. C. Wong, B. W. Darvell, K. D. K. Luk and W. W. Lu, Acta Biomater., 2009, 5, 1678-1685.

56 M. H. Alkhraisat, C. Rueda and E. López Cabarcos, J. Funct. Biomater., 2011, 2, 31-38.

57 A. A. Mirtchi, J. Lemaître and N. Terao, Biomaterials, 1989, 10, 475-480. 
58 M. Bohner and U. Gbureck, J. Biomed. Mater. Res., Part B, 2008, 84, 375-385.

59 M. Bohner, J. Lemaître and T. A. Ring, J. Am. Ceram. Soc., 1996, 79, 1427-1434.

60 B. R. Constantz, B. M. Barr, I. C. Ison, M. T. Fulmer, J. Baker, L. McKinney, S. B. Goodman, S. Gunasekaren, D. C. Delaney, J. Ross and R. D. Poser, J. Biomed. Mater. Res., 1998, 43, 451-461.

61 D. Apelt, F. Theiss, A. O. El-Warrak, K. Zlinszky, R. Bettschart-Wolfisberger, M. Bohner, S. Matter, J. A. Auer and B. von Rechenberg, Biomaterials, 2004, 25, 1439-1451.

62 A. Malsy and M. Bohner, Eur. Cells Mater., 2005, 10, 28.

63 Z. Xia, L. M. Grover, Y. Huang, I. E. Adamopoulos, U. Gbureck, J. T. Triffitt, R. M. Shelton and J. E. Barralet, Biomaterials, 2006, 27, 4557-4565.

64 Y. W. Li, J. C. Y. Leong, W. W. Lu, K. D. K. Luk, K. M. C. Cheung, K. Y. Chiu and S. P. Chow, J. Biomed. Mater. Res., 2000, 52, 164-170.

65 C. Drouet, M.-T. Carayon, C. Combes and C. Rey, Mater. Sci. Eng., C, 2008, 28, 1544-1550.

66 I. R. de Lima, G. G. Alves, C. A. Soriano, A. P. Campaneli, T. H. Gasparoto, E. S. Ramos Jr., L. de Sena, A. M. Rossi and J. M. Granjeiro, J. Biomed. Mater. Res., Part A, 2011, 98, 351-358.

67 E. Rokita, C. Hermes, H. F. Nolting and J. Ryczek, J. Cryst. Growth, 1993, 130, 541-552.

68 A. Bigi, E. Boanini, C. Capuccini and M. Gazzano, Inorg. Chim. Acta, 2007, 360, 1009-1016.

69 J. E. Huheey, E. A. Keiter, R. L. Keiter and R. Steudel, Anorganische Chemie/Prinzipien von Struktur und Reaktivität, de Gruyter, Berlin [u.a.], 3 edn, 2003.

70 E. Landi, A. Tampieri, G. Celotti, S. Sprio, M. Sandri and G. Logroscino, Acta Biomater., 2007, 3, 961-969.

71 M. D. O’Donnell, Y. Fredholm, A. de Rouffignac and R. G. Hill, Acta Biomater., 2008, 4, 1455-1464.

72 A. Bigi, E. Foresti, M. Gandolfi, M. Gazzano and N. Roveri, J. Inorg. Biochem., 1997, 66, 259-265.

73 S. J. Saint-Jean, C. L. Camire, P. Nevsten, S. Hansen and M. P. Ginebra, J. Mater. Sci.: Mater. Med., 2005, 16, 993-1001.

74 M. H. Alkhraisat, C. Moseke, L. Blanco, J. E. Barralet, E. López Carbacos and U. Gbureck, Biomaterials, 2008, 29, 4691-4697.

75 S. Panzavolta, P. Torricelli, L. Sturba, B. Bracci, R. Giardino and A. Bigi, J. Biomed. Mater. Res., Part A, 2008, 84, 965-972.

76 U. Gbureck, J. E. Barralet, K. Spatz, L. M. Grover and R. Thull, Biomaterials, 2004, 25, 2187-2195.

77 K. S. TenHuisen and P. W. Brown, J. Biomed. Mater. Res., 1997, 36, 306-314.

78 M. Bohner, H. Tiainen, P. Michel and N. Döbelin, J. Mater. Sci.: Mater. Med., 2015, 26, 63.

79 H.-B. Pan, Z.-Y. Li, T. Wang, W. M. Lam, C. T. Wong, B. W. Darvell, K. D. K. Luk, Y. Hu and W. W. Lu, Cryst. Growth Des., 2009, 9, 3342-3345.
80 L. C. Chow, Dent. Mater. J., 2009, 28, 1-10.

81 G.-M. Kuang, W. P. Yau, W. M. Lam, J. Wu, K. Y. Chiu, W. W. Lu and H. Pan, J. Biomed. Mater. Res., Part B, 2012, 100, 778-787.

82 M. Watanabe, M. Tanaka, M. Sakurai and M. Maeda, J. Eur. Ceram. Soc., 2006, 26, 549-552.

83 D. Guo, K. Xu, X. Zhao and Y. Han, Biomaterials, 2005, 26, 4073-4083.

84 D. Guo, M. Mao, W. Qi, H. Li, P. Ni, G. Gao and K. Xu, J. Mater. Sci.: Mater. Med., 2011, 22, 2631-2640.

85 S. Tadier, R. Bareille, R. Siadous, O. Marsan, C. Charvillat, S. Cazalbou, J. Amédée, C. Rey and C. Combes, J. Biomed. Mater. Res., Part B, 2011, 100B, 378-390.

86 M. Schumacher, A. Henß, M. Rohnke and M. Gelinsky, Acta Biomater., 2013, 9, 7536-7544.

87 X. Wang, J. Ye and Y. Wang, Acta Biomater., 2007, 3, 757-763. 88 G. Romieu, X. Garric, S. Munier, M. Vert and P. Boudeville, Acta Biomater., 2010, 6, 3208-3215.

89 X. Wang and J. Ye, J. Mater. Sci.: Mater. Med., 2008, 19, 1183-1186.

90 T. Yu, J. Ye and Y. Wang, Acta Biomater., 2009, 5, 2717-2727.

91 M. Baier, P. Staudt, R. Klein, U. Sommer, R. Wenz, I. Grafe, P. J. Meeder, P. P. Nawroth and C. Kasperk, J. Orthop. Surg. Res., 2013, 8, 16.

92 Y. Shen, J. Liu, K. Lin and W. Zhang, Mater. Lett., 2012, 70, 76-79.

93 E. Fujihara, M. Kon and K. Asaoka, Key Eng. Mater., 2007, 330-332, 795-798.

94 L. Leroux, M. Frèche and J. Lacout, Key Eng. Mater., 2001, 192-195, 235-238.

95 S. Pina, P. M. Torres, F. Goetz-Neunhoeffer, J. Neubauer and J. M. F. Ferreira, Acta Biomater., 2010, 6, 928-935.

96 S. Pina, P. M. C. Torres and J. M. F. Ferreira, J. Mater. Sci.: Mater. Med., 2010, 21, 431-438.

97 E. Boanini, S. Panzavolta, K. Rubini, M. Gandolfi and A. Bigi, Acta Biomater., 2010, 6, 936-942.

98 M. Schumacher, A. Lode, A. Helth and M. Gelinsky, Acta Biomater., 2013, 9, 9547-9557.

99 S. Heinemann, S. Rössler, M. Lemm, M. Ruhnow and B. Nies, Acta Biomater., 2013, 9, 6199-6207.

100 M. Bohner, U. Gbureck and J. Barralet, Biomaterials, 2005, 26, 6423-6429.

101 S. C. Verberckmoes, G. J. Behets, L. Oste, A. R. Bervoets, L. V. Lamberts, M. Drakopoulos, A. Somogyi, P. Cool, W. Dorriné, M. E. De Broe and P. C. D’Haese, Calcif. Tissue Int., 2004, 75, 405-415.

102 A. Reinstorf, U. Hempel, F. Olgemöller, H. Domaschke, W. Schneiders, R. Mai, B. Stadlinger, A. Rösen-Wolff, S. Rammelt, M. Gelinsky and W. Pompe, Materialwiss. Werkstofftech., 2006, 37, 491-503.

103 J. Gustavsson, M. P. Ginebra, E. Engel and J. Planell, Acta Biomater., 2011, 7, 4242-4252.

104 S. Maeno, Y. Niki, H. Matsumoto, H. Morioka, T. Yatabe, A. Funayama, Y. Toyama, T. Taguchi and J. Tanaka, Biomaterials, 2005, 26, 4847-4855. 
105 Y. K. Liu, Q. Z. Lu, R. Pei, H. J. Ji, G. S. Zhou, X. L. Zhao, R. K. Tang and M. Zhang, Biomed. Mater., 2009, 4, 025004.

106 D. Guo, K. Xu and Y. Han, J. Biomed. Mater. Res., Part A, 2008, 86, 947-958.

107 G.-M. Kuang, W. P. Yau, J. Wu, K. W. K. Yeung, H. Pan, W. M. Lam, W. W. Lu and K. Y. Chiu, J. Biomed. Mater. Res., Part A, 2014, 00A, 1552-4965.

108 D. R. Carter and W. C. Hayes, J. Bone Jt. Surg., Am. Vol., 1977, 59, 954-962.

109 E. Charriere, S. Terrazzoni, C. Pittet, P. H. Mordasini, M. Dutoit, J. Lemaître and P. H. Zysset, Biomaterials, 2001, 22, 2937-2945.

110 G. Cama, F. Barberis, R. Botter, P. Cirillo, M. Capurro, R. Quarto, S. Scaglione, E. Finocchio, V. Mussi and U. Valbusa, Acta Biomater., 2009, 5, 2161-2168.

111 H. Andrianjatovo, F. Jose and J. Lemaître, J. Mater. Sci.: Mater. Med., 1996, 7, 34-39.

112 O. Bermúdez, M. Boltong, F. C. Driessens and J. Planell, J. Mater. Sci.: Mater. Med., 1993, 4, 389-393.

113 J. Engstrand, J. Jacob, H. Engqvist and C. Persson, in The 23rd Interdisciplinary Research Conference on Injectable Osteoarticular Biomaterials and Bone Augmentation Procedures - GRIBOI: Proceedings, 2013.

114 A. López, M. Montazerolghaem, H. Engqvist, M. K. Ott and C. Persson, J. Biomed. Mater. Res., Part B, 2014, 102, 250-259.

115 V. Medri, M. Mazzocchi and A. Bellosi, J. Mater. Sci.: Mater. Med., 2011, 22, 229-236.

116 M. Rohnke, A. Henß, J. Kokesch-Himmelreich, M. Schumacher, S. Ray, V. Alt, M. Gelinsky and J. Janek, Anal. Bioanal. Chem., 2013, 405, 8769-8780.

117 S. Pina, S. I. Vieira, P. Rego, P. M. C. Torres, O. A. B. da Cruz e Silva, E. F. da Cruz e Silva and J. M. F. Ferreira, Eur. Cells Mater., 2010, 20, 162-177.
118 L. Yang, S. Perez-Amodio, F. Y. F. Barrère-de Groot, V. Everts, C. A. van Blitterswijk and P. Habibovic, Biomaterials, 2010, 31, 2976-2989.

119 Y. L. Ma, Q. Q. Zeng, L. L. Porras, A. Harvey, T. L. Moore, T. L. Shelbourn, G. P. Dalsky, T. J. Wronski, J. I. Aguirre, H. U. Bryant and M. Sato, Endocrinology, 2011, 152, 1767-1778.

120 G. X. Ni, K. Y. Chiu, W. W. Lu, Y. Wang, Y. G. Zhang, L. B. Hao, Z. Y. Li, W. M. Lam, S. B. Lu and K. D. K. Luk, Biomaterials, 2006, 27, 4348-4355.

121 W. W. Lu, K. M. Cheung, Y. W. Li, K. D. Luk, A. D. Holmes, Q. A. Zhu and J. C. Leong, Spine, 2001, 26, 2684-2690.

122 Z. Li, N. Yuan, R. W. M. Lam, Z. Cui, X. Yang and W. W. Lu, Mater. Sci. Eng., C, 2013, 33, 5100-5104.

123 C. T. Wong, W. W. Lu, W. K. Chan, K. M. C. Cheung, K. D. K. Luk, D. S. Lu, A. B. M. Rabie, L. F. Deng and J. C. Y. Leong, J. Biomed. Mater. Res., Part A, 2004, 68, 513-521.

124 C. T. Wong, Q. Z. Chen, W. W. Lu, J. C. Y. Leong, W. K. Chan, K. M. C. Cheung and K. D. K. Luk, J. Biomed. Mater. Res., Part A, 2004, 70, 428-435.

125 G.-M. Kuang, W. P. Yau, W. W. Lu and K. Y. Chiu, Am. J. Sports Med., 2014, 42, 2996-3002.

126 V. Alt, U. Thormann, S. Ray, D. Zahner, L. Dürselen, K. Lips, T. El Khassawna, C. Heiss, A. Riedrich, G. Schlewitz, A. Ignatius, M. Kampschulte, H. von Dewitz, S. Heinemann, R. Schnettler and A. Langheinrich, Acta Biomater., 2013, 9, 7035-7042.

127 U. Thormann, S. Ray, U. Sommer, T. ElKhassawna, T. Rehling, M. Hundgeburth, A. Henß, M. Rohnke, J. Janek, K. S. Lips, C. Heiss, G. Schlewitz, G. Szalay, M. Schumacher, M. Gelinsky, R. Schnettler and V. Alt, Biomaterials, 2013, 34, 8589-8598. 